\title{
WHEN MONEY GREW ON TREES: LUCY $V$. ZEHMER AND CONTRACTING IN A BOOM MARKET
}

\author{
BARAK RICHMAN $\dagger$
}

DENNIS SCHMELZER ††

A farmer and a lumberman are sitting at a bar. The lumberman says: "I would like to buy your farm." The farmer says: "What is this, some kind of joke?"

\begin{abstract}
This Article revisits Lucy v. Zehmer, a 1950s Virginia Supreme Court ruling that has become a staple in most contracts courses in American law schools. The colorful facts are well known to nearly all law students: Lucy and Zehmer met one evening in December 1952 at a restaurant in Dinwiddie, Virginia, and, following several drinks and much verbal banter, Zehmer wrote a contract on a restaurant bill, in which he agreed to sell his farm to Lucy for \$50,000. Zehmer later insisted that he had been intoxicated and had thought the entire matter was a joke. He testified that he had been "high as a Georgia pine" and merely bluffing to try to get Lucy to admit that he did not actually have \$50,000. Upholding the contract, the court ruled that regardless of Zehmer's intent, his outward behavior could reasonably be construed to suggest that he had been serious. The court thus invoked what is known as the "objective theory of contract formation."
\end{abstract}

Copyright (C) 2012 by Barak Richman \& Dennis Schmelzer.

$\dagger$ Professor of Law and Business Administration, Duke University School of Law.

$\dagger \dagger$ Associate, White \& Case LLP. Neither White \& Case LLP nor its clients espouses the views expressed in this Article.

The authors express profound thanks to the many individuals who shared their family histories, archives, and lore, including John C. Lucy Jr., John C. Lucy III, John C. Lucy IV, James "Sawyer" Lucy, Meade Lucy, Emory Lucy, Floyd M. Harrison Jr., Richard Liles, and Ronald Seagrave. Special thanks also goes to Frank Snyder, for sharing an early interest in the project and providing inspiration with an unrivaled slideshow; to Paul Haagen, who reviewed an early version of this manuscript with exceptional care; and to Mary Dudziak, Ed Balleisin, and the Triangle Legal History Workshop. Additional thanks to Jonathan Calmore, Jacob Johnson, Sarah Kahn, Laura Lucas, Lyndsey Morgan, Donna Nixon, and, especially, Jennifer Behrens for exceptional research support. 
Our findings suggest that the court misinterpreted the contractual setting surrounding that December evening in 1952. Our research uncovers several discoveries: (1) Lucy, acting as a middleman for southern Virginia's burgeoning pulp-and-paper industry, sought the Ferguson farm for its rich timber reserves; (2) Lucy was one of scores of aggressive timber middlemen in the region who eagerly sought valuable timberland and prompted a chaotic landgrab, leaving a wake of shady transactions and colorful litigation; and (3) within eight years of winning injunctive relief from the Virginia Supreme Court and purchasing the Ferguson farm from Zehmer for \$50,000, Lucy earned approximately $\$ 142,000$ from selling the land and its natural resources. These findings call into question the court's assertion that $\$ 50,000$ was a fair price, its conclusion that Zehmer's actions indicated contractual intent, and its confidence that the objective method captured the relevant background in which Lucy's and Zehmer's exchange took place. More generally, these findings suggest that conclusions reached by the objective method are highly dependent on both the facts that are retold and the context in which those facts occurred, and that historical analysis can meaningfully illustrate the limits of legal doctrines.

\section{TABLE OF CONTENTS}

Introduction

I. The View from Richmond ...............................................................1517

A. A Matter of Mysterious Motivations................................1519

B. The \$50,000 Question ....................................................1522

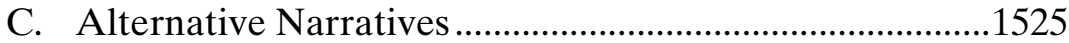

II. The Farmer and the Lumberman ................................................1531

III. Timber Prices, Land Disputes, and an Industrial Shift in the

South

A. When the Farmer Met the Lumberman: Timber's Early Years

B. The Post-World War II Boom ...........................................1540

C. Southern Industry and Southern Law: The Rise of the Timber Broker.

D. The Timber Broker and the Courtroom .........................1547

IV. Not Just a Tale of Two Lumbermen .........................................1551

A. The Secret to the Lucys' Success ......................................1552

B. Answering the $\$ 50,000$ Question.......................................1553

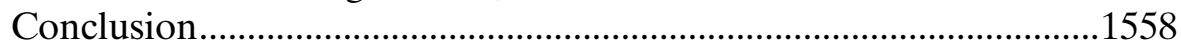

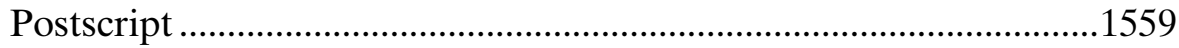




\section{INTRODUCTION}

Many good stories begin with two men at a bar. Lucy v. Zehmer, "a staple of contracts casebooks since shortly after it was decided" in $1954,{ }^{2}$ is no exception. As generations of law students have learned, the case of Lucy v. Zehmer involved two men talking over a bottle of liquor the weekend before Christmas. ${ }^{3}$ Adrian Hardy Zehmer, allegedly drunk and joking, scribbled a contract for the sale of his farm on the back of a receipt. ${ }^{4}$ Welford Ordway Lucy accepted and left, insisting that Zehmer was bound to the sale. ${ }^{5}$ The Virginia Supreme Court ultimately agreed with Lucy, ruling that a signed contract, even one signed by two men drinking at a bar, is no laughing matter. $^{6}$

1. Lucy v. Zehmer, 84 S.E.2d 516 (Va. 1954).

2. See Keith A. Rowley, You Asked for It, You Got It . . Toy Yoda: Practical Jokes, Prizes, and Contract Law, 3 NEV. L.J. 526, 527 n.7 (2003) (noting that Lucy v. Zehmer appears as a "principal case" in ten of fifteen contract-law casebooks published between 2000 and 2003 and is discussed in a "lengthy note" in an eleventh); see also IAN AYRES \& RICHARD E. SPEIDEL, STUdies IN CONTRACT LAW 229 (7th ed. 2008); RANDY E. BARNETT, CONTRACTS: CASES AND DOCTRINE 296 (4th ed. 2008); Brian A. Blum \& AMY C. BUSHAw, ContraCtS: CASES, Discussion, AND Problems 71 (2d ed. 2008); STEVEN J. BURTON, PRINCIPLES OF Contract LaW 11 (3d ed. 2006); John D. Calamari, Joseph M. Perillo, Helen HadjIYANNAKIS BENDER \& CAROLINE N. BRown, CASES AND PRoblems ON CONTRACTS 1 (5th ed. 2007); DAVID G. EPSTEIN, BRUCE A. MARKELl \& LAWRENCE PONOROFF, CASES AND MATERIALS ON CONTRACTS: MAKING AND DoING DEALS 37 (3d ed. 2011); E. AllaN FARnsworth, William F. Young, CAROl SANGer, NeIl B. COHEN \& Richard R.W. BRooks, CONTRACTS: CASES AND MATERIALS 117 (7th ed. 2008); LON L. FULLER \& MELVIN ARON EISENBERG, BASIC CONTRACT LAW 370 (8th ed. 2006); JOHN EDWARD MURRAY, JR., CONTRACTS: CASES AND MATERIALS 52 (5th ed. 2000); ROBERT E. SCOTT \& JODY S. KRAUS, CONTRACT LAW AND THEORY 13 (4th ed. 2007); Robert S. SUMMERS \& ROBERT A. Hillman, Contract and Related Obligation: Theory, Doctrine, AND PRactice 441 (6th ed. 2010); Kenneth M. Alfano, Copyright in Exile: Restoring the Original Parameters of Exclusive Reproduction, 11 J. TECH. L. \& POL'Y 215, 242 n.117 (2006) (noting that Lucy v. Zehmer "is a fixture of many law school Contracts casebooks"); Douglas L. Leslie, How Not To Teach Contracts, and Any Other Course: Powerpoint, Laptops, and the Casefile Method, 44 ST. LoUIS U. L.J. 1289, 1300 (2000) (commenting on the "frequency with which Lucy v. Zehmer" appears in contracts casebooks).

3. Lucy, 84 S.E.2d at 519 ("I was already high as a Georgia pine, and didn't have any more better sense than to pour another great big slug out and gulp it down, and he took one too." (quoting Hardy Zehmer) (internal quotation marks omitted)).

4. Id. at $517-18$.

5. Id. at 518 .

6. See id. at 522 ("The complainants are entitled to have specific performance of the contract sued on."). The Virginia Supreme Court of Appeals was the highest court in Virginia at the time. Due to changes made in the Virginia Constitution of 1971, the court today is known as the Supreme Court of Virginia. THE SUPREME COURT OF VIRGINIA (2010), available at http:// www.courts.state.va.us/courts/scv/scvinfo.pdf. To avoid confusion, we refer to the court by its present, rather than its historic, title. 
That is, at least, the conventional story of the case, as told by the court, subsequent casebooks, and scholarly articles. ${ }^{7}$ For the most part, Lucy v. Zehmer is narrowly read to represent its final holding: a court will only look to the outwardly manifested conduct of the parties to determine contractual intent. ${ }^{8}$ This principle, also referred to as the "objective theory of contracts," remains as solidly entrenched in law in 2012 as when the court's opinion was issued more than five decades ago. ${ }^{10}$ And even though the case presents a straightforward legal issue, stemming from what appeared to be a

7. See, e.g., Edwin W. Patterson, An Apology for Consideration, 58 COLuM. L. REV. 929, 957 (1958) (noting that the court in Lucy v. Zehmer held that a promisor who "signed [a] document as a joke although he kept a straight face to the promisee" was bound to keep that promise). Professors Edwin Patterson, George Goble, and Harry Jones were among the first to include the case in a casebook. In their book, these authors questioned whether Lucy had known that Zehmer had been joking and whether that fact mattered. See EDWIN W. Patterson, George W. Goble \& Harry W. Jones, Contracts 22-26 (4th ed. 1957) ("Suppose the plaintiff knew that the defendant in the principal case intended the matter as a joke. What should be the result?"); see also Keith A. Rowley, Beware of the Dark Side of the Farce, 10 NEV. L.J. 15, 15 (2002) ("The case best known to most lawyers and judges in which a party attempted to avoid contractual liability on the basis that it was only kidding when it made the alleged promise or formed the alleged contract is Lucy v. Zehmer."); Lauren E. Miller, Note, Breaking the Language Barrier: The Failure of the Objective Theory To Promote Fairness in Language-Barrier Contracting, 43 IND. L. REV. 175, 183 (2009) (citing Lucy v. Zehmer for the principle that a contract is still enforceable when a party claims to have been joking when the contract was signed).

8. See, e.g., Timothy S. Hall, Magic and Contract: The Role of Intent, 12 TEX. WESLEYAN L. REV. 464, 466 (2005) (noting that Lucy v. Zehmer is "studied by many first-year law students" to demonstrate the "elementary principle of contracts that the relevant intent is the objective, expressed intent of the actor, not his secret, subjective intent"); Laura E. Little, Regulating Funny: Humor and the Law, 94 CORNELL L. REV. 1235, 1258 (2009) (citing Lucy v. Zehmer for the proposition that a person cannot claim that he was just joking when his words and conduct would lead a reasonable person to believe otherwise).

9. See Lawrence M. Solan, Contract as Agreement, 83 Notre DAME L. REV. 353, 381 (2007) (explaining that Lucy v. Zehmer is one of the "classic cases" used to demonstrate the "objective theory of contracts"); see also Wayne Barnes, The Objective Theory of Contracts, 76 U. CIN. L. REV. 1119, 1125 (2008) (describing Lucy v. Zehmer as "an illustrative case" of the principles embodied by the objective theory of contracts); Christopher R. Drahozal, Privatizing Civil Justice: Commercial Arbitration and the Civil Justice System, 9 KAN. J.L. \& PUB. POL'Y 578, 578 (2000) (describing the conflict in Lucy v. Zehmer as one between "the objective versus subjective theory of contract"); Geoffrey R. Watson, A Casebook for All Seasons?, 20 SEATTLE U. L. ReV. 277, 282 (1997) (reviewing E. Allen FARnsworth \& William F. Young, CASES AND MATERIALS ON CONTRACTS (5th ed. 1995)) (calling Lucy v. Zehmer "an excellent introduction to the objective theory of contract").

10. See Solan, supra note 9, at 354-55 ("The actual states of mind of the parties are not the subject of legally relevant inquiry. ... While there is some debate about how and when this state of affairs developed, there is little controversy about its existence." (footnote omitted)). 
remarkably simple contract, ${ }^{11}$ its story-in large part because of its colorful fact pattern - has become a "classic case[]" used to introduce foundational principles related to intent in contracts. ${ }^{12}$ Despite this attention, little more is known about the case than what is found in the Virginia Supreme Court's opinion. Given the case's prominence in contracts casebooks for more than half a century, and given the growing body of "stories" research into other prominent and classic cases, ${ }^{13}$ the dispute between Welford Lucy and Hardy Zehmer begs to be included in the archive of stories. ${ }^{14}$

Delving into the story of Lucy v. Zehmer, like many of the other stories inquiries, yields surprises and lessons that both inform the contemporary understanding of the case and generate deeper insights into contract law. First, just as scholarly articles suggest that the famous property case about a stolen fox was not really about the fox ${ }^{15}$ and that the famous contracts case about a bridge was not primarily about the bridge, ${ }^{16}$ the dispute in Lucy $v$. Zehmer was not primarily

11. See Stephen M. Edwards, Purchase and Sale Agreements, in 1 Mass. ContinuING LEgAl EDUC., INC., DRAFTING COMMERCIAL REAL ESTATE DOCUMENTS IN MASSACHUSETTS ch. 2, § 2.2 (2004 \& Supp. 2009), available at Westlaw, DCREDMAI MACLE 2-1 (noting the admirable succinctness of the agreement involved in the case).

12. Impracticable Presidents, 6 GREEN BAG 2D 417, 417 (2003). For the same reasons, the case is also a favorite example in undergraduate business-law courses. See, e.g., JOHN E. ADAMSON, LAW FOR PERSONAL AND BUSINESS USE 168 (18th ed. 2008) (offering the Lucy $v$. Zehmer fact pattern as an example and asking whether the contract should be enforceable); Frank B. CROSS \& Roger LERoy MiLler, THE LEGAl ENVIRONMENT OF BUSINESS: TEXT AND CASES 200-01 (7th ed. 2009) (using Lucy v. Zehmer to illustrate how courts approach contractual intent).

13. See, e.g., CONTRACTS StORIES (Douglas G. Baird ed., 2007) (gathering eleven different articles, each providing newly uncovered facts about and insight into eleven principal cases used by many contracts casebooks).

14. Professors Robert Scott and Jody Kraus offer an initial hypothesis about what motivated the parties to this dispute, relying on unsubstantiated rumors relayed by a former student who grew up in Dinwiddie, but they note that even their hypothesis leaves numerous questions unanswered. ROBERT E. SCOTT \& JODY S. KRAUS, CONTRACT LAW AND THEORY: TEACHER'S MANUAL 4-5 (3d ed. 2003). We address their hypothesis-and the questions they pose-in our first Part.

15. Bethany R. Berger, It's Not About the Fox: The Untold History of Pierson v. Post, 55 Duke L.J. 1089, 1089 (2006) (arguing that "the heart of the conflict [in Pierson v. Post, 3 Cai. 175 (N.Y. Sup. Ct. 1805),] was a contest over which community would control the shared resources of the town and how those resources would be used," rather than over literal ownership of the dead fox that was at the center of the lawsuit).

16. Barak Richman, Jordi Weinstock \& Jason Mehta, A Bridge, a Tax Revolt, and the Struggle To Industrialize: The Story and Legacy of Rockingham County v. Luten Bridge Co., 84 N.C. L. REV. 1841, 1841-42 (2006) (explaining how a famous case "used to illustrate the "duty to mitigate" in many contracts casebooks was actually rooted in a "dispute . . about the legitimacy of local government"). 
about the Ferguson farm. Instead, the lawsuit was part of a larger upheaval over the control of increasingly valuable timber resources in the wake of a Southern revolution in pulp-and-paper production. Moreover, that this underlying context of the case remained secret for so long was no accident. The context's relative obscurity is a testament to a deliberate and successful effort by the Southern timber industry, in an attempt to minimize public outcry, to acquire timber and timberlands through intermediaries like Welford Lucy. That the context has remained hidden is also a reflection of how economic circumstances and contractual environments can be concealed both from an appellate court's review and from generations of scrutinizing students.

Although the case is more than five decades old, the trail of documentary evidence is sufficient to tell a more complete story of Lucy v. Zehmer. We tell this story in four Parts. First, we take a closer look at the order of the trial court and the opinion of the Virginia Supreme Court, identifying inconsistencies and other curiosities in the later court's story. Second, we describe the parties to the lawsuit, taking care to go beyond the narrow caricatures provided by the court and introducing some important characters-including the lawyerswho are not part of the traditional narrative. Third, we examine the history of the lumber and paper industries of southern Virginia and the state's industrial revolution through the 1950s, the time period when the dispute and litigation over the Ferguson farm occurred. The region's rapid post-World War II industrialization induced significant changes in the region's technology, business models, and timberland values, which in turn led to conflicts between neighbors and significant litigation. This economic and social tumult is central to understanding the context in which Welford Lucy's momentous meeting with Hardy Zehmer occurred. And fourth, we discuss the Lucy brothers' significant roles in the lumber industry, their success as industry middlemen, and what might have caused them to litigate over the Ferguson farm. In light of our findings, we reexamine the Virginia Supreme Court's opinion-in particular, revisiting its conclusion that the transaction was fair and equitable and trying to appreciate the broader forces at work when Lucy entered Zehmer's diner on December 20, 1952.

Perhaps most significant, our findings reveal deficiencies in the objective theory of contracts, the very doctrine that Lucy v. Zehmer has come to represent. The Virginia Supreme Court ruled on Lucy's behalf because it concluded that the events of that December evening 
would have led a reasonable person to believe that Zehmer intended to enter into a contract. ${ }^{17}$ Unmentioned in the court's narrative are important features of the economic and legal environment that surrounded the encounter: significant growth in southern Virginia's pulp-and-paper industry, a consequent sharp rise in timber prices, and a landgrab by zealous timber brokers that generated spurious land sales and tedious work for southern Virginia's courtrooms. If the court had considered these facts in its description of Lucy's fateful conversation with Zehmer, a reasonable person may have been less likely to conclude that Zehmer intended to be contractually bound. In short, historical analysis not only reveals deficiencies in the court's reasoning but also illustrates that the objective method generates conclusions that are highly dependent on the surrounding narrative. Historians' ability to construct alternative narratives therefore highlights the legal value of historical analysis while weakening the robustness of the objective theory itself.

\section{THE VIEW FROM RICHMOND}

Most of Lucy v. Zehmer's central events took place in Dinwiddie County, Virginia, a rural community located between Richmond and the North Carolina border and home to several pivotal Civil War battles in early $1865 .{ }^{18}$ Dinwiddie's economy was historically agrarian, relying chiefly on tobacco and cotton in the early twentieth century. ${ }^{19}$ Although a mere forty miles separate Dinwiddie and Richmond, Virginia's state capital, the Dinwiddie court viewed Lucy's dispute with Zehmer quite differently from the supreme court in Richmond, and the unusual interplay between the trial and appellate courts hints at these different vantage points. In fact, even a surface examination

17. Lucy v. Zehmer, 84 S.E.2d 516, 522 (Va. 1954).

18. For a detailed description of Dinwiddie during the Civil War, see RICHARD L. JONES, DinWIDdie COUNTY: CARREFOUR OF THE COMMONWEALTH 134-64 (1976). See generally A. Wilson Greene, The final Battles of the Petersburg Campaign: Breaking the BACKBONE OF THE REBELLION 175-84 (2d ed. 2008) (describing the events leading from the Battle of Dinwiddie Courthouse to the Battle of Five Forks); Dallas D. Irvine, The Fall of Richmond: Evacuation and Occupation, 3 J. AM. MIL. INST. 66 (1939) (describing how the battles in Dinwiddie County "made it imperative to prepare at once for evacuation of the position on the James").

19. Walter Gordon Browder \& Linwood Everett Lunsford, An Economic and Social Survey of Dinwiddie County, UNIV. OF VA. RECORD EXTENSION SERIES, Oct. 1937, at 1, 54-55 ("[T] he county is almost entirely agrarian, and the livelihood of the citizens depends upon the fertility and productiveness of the soil ... . Tobacco is the leading cash crop . . . Cotton is the next most important crop in the county ...."). 
of the Virginia Supreme Court's opinion in Lucy v. Zehmer leaves the casual reader with some curiosities.

To begin with, in contrast to the appellate court's embellishment of the case's amusing and flavorful fact pattern, the trial court disposed of the case with a humorless and expedient order. ${ }^{20}$ After hearing initial arguments from attorneys on both sides and reviewing the slim record of evidence-a brief series of depositions taken in the Brunswick and Dinwiddie County courts before trial-trial Judge John Garland Jefferson Jr. promptly dismissed the action in a threesentence decree.$^{21} \mathrm{He}$ ruled simply that the Lucy brothers had "failed to establish their right to specific performance of the alleged contract." 22

Perhaps because of the absence of factual determinations from the trial court, Justice Archibald C. Buchanan provided an elaborate description of the relevant events when he overturned the order. ${ }^{23}$ These circumstances placed the Virginia Supreme Court in the unusual position of being an initial finder of fact, producing an appellate opinion many times longer, and much more in depth, than the trial court's ruling. Moreover, Justice Buchanan discarded the lower court's decision with gusto, finding the contract to be both legitimate and enforceable and ridiculing Zehmer's lawyers for advancing "an unusual, if not bizarre, defense." ${ }^{24}$ Rather than remanding the case to the trial court to determine whether additional evidence would support the appellate court's lengthy characterization of the facts, the Virginia Supreme Court handed Lucy a final victory, allowing him to take possession of the disputed Ferguson farm. ${ }^{25}$

In addition to this unusual dynamic between the trial and appellate courts, Justice Buchanan's famous opinion has its own contradictions and mysteries, very few of which have attracted

20. Record at 9, Lucy, 84 S.E.2d 516 (No. 4272).

21. Id. The evidence relied upon is largely contained in a set of depositions of witnesses taken in the courthouse of the town of Lawrenceville in neighboring Brunswick County, Virginia. See generally id. at 10-84 (compiling the depositions taken in preparation for trial).

22. Id. at 518 .

23. See generally Lucy, 84 S.E.2d at 516-20 (leading the reader through the facts as laid out in opposing testimony before delving into the legal issues presented by both parties to the appeal).

24. Id. at 520.

25. Id. at 522-23; see also Deed (1954), in 90 DINWIDDIE COUNTY DEED BOOK 365, $365-$ 66 (containing a copy of the deed confirming the transfer of the Ferguson farm from A.H. Zehmer to W.O. Lucy). 
attention from legal scholars. ${ }^{26}$ Scrutinizing this oft-told but unquestioned legal tale illuminates where historical analysis might offer lessons.

\section{A. A Matter of Mysterious Motivations}

On the surface, the case described by Justice Buchanan appears to be a local dispute between two relatively unsophisticated neighbors. Lucy was a "lumberman and farmer"; Zehmer "operated a restaurant, filling station and motor court"; $;$ and the contract appeared to be informal, uncalculated, and driven by liquor, even if the court did not ultimately believe that the men had been legally intoxicated at the time. ${ }^{28}$ In Dinwiddie County, this view has persisted; fifty years later, one community leader still described the dispute as arising out of "a little alcohol, cards and greed."

The record provides a reasonable basis for concluding that the dispute was the result of impulsive action. Testifying that he had been

26. Among the few who have given some scrutiny to the famous case is the noted legal scholar Professor Allan Farnsworth, who raises a significant timing issue in the case. See E. Allan FARnsworth, CHANGING Your Mind: THE LAW OF REGRETTED DeCisions 55-65 (1998) ("[T]he Zehmers were already bound by their promise, even though there was no possibility that [Lucy] had relied on it in the few seconds between the exchange of promises and [Zehmer's] protestation. But why?"). Pointing to Zehmer's allegations that he had reneged on his promise shortly after signing the contract and that he had subsequently refused the $\$ 5$ offered by Lucy for consideration that same night, Professor Farnsworth questions whether such actions are consistent with the court's ultimate conclusion that the contract was valid. Id. at 56 . Farnsworth argues that this almost-immediate repudiation of the contract raises crucial questions about exactly when the contract was formed between the parties and what effect Zehmer's subsequent statements should have had on Lucy's reliance. Id. Nonetheless, Farnsworth ultimately defends the court's decision to uphold the contract despite these issues with timing, arguing that once a contract is signed, it does not matter when a party reneges on that contract. $I d$. at 58. Farnsworth argues that the law presumes that reliance takes place whether disagreement is expressed two minutes or two weeks after a contract's consummation. Id. at 59. In response, Professor Richard Spiedel points out that Lucy actually contested these facts and that, ultimately, the court instead accepted Lucy's statements that he had already raised the $\$ 50,000$ and had consulted his lawyer about the transaction before Zehmer communicated his refusal to sell. Richard E. Spiedel, 31 LOY. U. CHI. L.J. 255, 267 n.57 (2000) (reviewing FARNSWORTH, supra); see also Lucy, 84 S.E.2d at 521-22 (providing the disputed text). Although only a small issue in the dispute, this timing question is particularly significant to those seeking to understand the overall contours of the court's final holding; after all, if what matters is the outwardly manifested "objective" intent, determining which outward manifestations the court will consider is important. The timing question is also heavily informed by the context and surrounding circumstances in which the purported assent takes place.

27. Lucy, 84 S.E.2d at 518.

28. See id. at 518-19 (describing the conditions of the negotiation).

29. Email from Richard Liles, President, Bank of McKenney, to author (Mar. 6, 2009, 08:46 AM) (on file with the Duke Law Journal). 
as "high as a Georgia pine," ${ }^{30}$ Zehmer and his attorneys argued that the alleged contract had been a joke between two "doggoned drunks." ${ }^{31}$ Zehmer had immediately retracted his purported acceptance, and the next day a presumably more sober Zehmer had informed Lucy that he had no intention of holding Lucy to the alleged agreement. ${ }^{32}$ Similarly, Lucy, in his own testimony, expressed some concern about the manner in which the agreement had been reached ${ }^{33}$ when asked by one of Zehmer's lawyers whether he had felt drunk or happy on the night of the signing, Lucy answered, "Looks like I must have been feeling rich." ${ }^{34}$

Even mildly dissecting the court's opinion reveals a calculated dispute with more significance than is portrayed in the conventional telling. If Zehmer had been reluctant to sell and Lucy had believed the price was too high, they would have had sufficient grounds to reach an amicable settlement to the supposedly spontaneous and illadvised agreement. But Lucy and Zehmer did not settle. To the contrary, Lucy promptly secured payment for the farm, and, when Zehmer refused to deliver title, Lucy hired an attorney and brought suit to compel performance. ${ }^{35}$ Then, when the trial court invalidated that contract-relieving Lucy of any obligation he might have felt to perform-Lucy pursued an appeal before the state's highest court, triggering a legal battle that presumably was costly and timeconsuming for both parties. ${ }^{36}$ If the procedural history of Lucy $v$. Zehmer reveals anything, it shows that Lucy's legal actions spoke much louder than his words of regret.

Moreover, Lucy did not hire just any attorney to enforce the contract-he sought Virginia's best. Albertis S. Harrison Jr. who

30. Lucy, 84 S.E.2d at 520 (quoting Zehmer) (internal quotation mark omitted).

31. Id. (quoting Zehmer's characterization of the encounter as "two doggoned drunks bluffing to see who could talk the biggest and say the most" (internal quotation mark omitted)). The court ultimately concluded that "Zehmer [had] not been intoxicated to the extent of being unable to comprehend the nature and consequences of the instrument he [had] executed, and hence that [the] instrument [wa]s not to be invalidated on that ground." Id.

32. Id. at 521 .

33. Id. The court noted that Lucy had admitted that he "[had] been stuck before and [would go] through with it." Id. (quoting Lucy) (internal quotation mark omitted).

34. Record, supra note 20 , at 63.

35. Id. at $46-48$.

36. The dispute lasted nearly two years, from the initial dispute through Zehmer's final conveyance of the property to the Lucy brothers. See Lucy, 84 S.E.2d at 517 (noting that the dispute began on December 20,1952); Deed, supra note 25, at 365 (recording the conveyance of the Ferguson farm to the Lucy brothers on December 17, 1954). 
represented Lucy at both the trial and the appellate level, ${ }^{37}$ was a legendary figure in Virginia. In the 1960s, at the height of his power, Harrison would serve as Virginia's governor and then as a justice on the Virginia Supreme Court. ${ }^{38}$ By 1952, Harrison's political clout had already started to rise. An ambitious state senator who was first elected to the state legislature in $1947,{ }^{39}$ Harrison's legendary status began to take shape when he took over as campaign manager for Senator Harry S. Byrd's 1952 reelection campaign during a tough year for the senator's political organization. ${ }^{40}$ Harrison was a natural choice five years later to be the Democratic candidate for attorney general of Virginia, ${ }^{41}$ a post that left him "responsible for handling in court the state's massive resistance strategy, a plan devised by Byrd to prevent federally ordered integration of the state's public schools." ${ }^{42}$ Later, Harrison was depicted by the press as the person responsible for keeping the Byrd machine running smoothly into the $1960 \mathrm{~s} .{ }^{43}$ In

37. Lucy, 84 S.E.2d at 517. Lucy was also represented by local judge Emerson D. Baugh, $i d$., a judge in Brunswick County. Although Judge Baugh did not have the same notoriety as Harrison, he evidently was a respected lawyer in southside Virginia. See 2 MARTINDALEHUBBELl LAW DIRECTORY 2444 (1956) (giving Judge Baugh a very high recommendation).

38. Wolfgang Saxon, Albertis S. Harrison Jr., 88, Dies; Led Virginia as Segregation Fell, N.Y. TIMES, Jan. 25, 1995, at B8.

39. Materials from this first election are available at the Governor Albertis Harrison Room of the Brunswick County Museum in Lawrenceville, Virginia. Copies of these materials are on file with the Duke Law Journal.

40. See, e.g., Peter R. Henriques, The Byrd Organization Crushes a Liberal Challenge, 1950-1953, 87 VA. MAG. HIST. \& BIOGRAPHY 1, 18 (1979) (describing how seriously Senator Byrd took a primary challenge from liberal Democrats and explaining that, to counter the challenge, "[a] knowledgeable state senator and future governor, Albertis S. Harrison, was tapped as Byrd's campaign manager").

41. Gay Neale with Henry L. Mitchell, JR. \& W.M. Pritchett, Brunswick COUNTY, VIRGINIA, 1720-1975, at 287 (1975).

42. Albertis Harrison, Governor 1962-66, DAILY PRESS (Newport News, Va.), Jan. 24, 1995, at B4, available at 1995 WLNR 4777880.

43. A political cartoon from July 13, 1961, for example, depicts Harrison's lasting influence with the Byrd machine even into the 1960s. In the cartoon, Harrison sits with his arm around Senator Byrd in a 1920s-era automobile labeled the Byrd Machine. The caption reads: "The old buggy runs as good as ever, Harry!" Allie Edward Stakes Stephens, another Byrd adviser, is depicted falling off the vehicle. The cartoon thus appears to show Harrison gaining influence in the Byrd Machine at the expense of Stephens. The cartoon is on file with the Duke Law Journal.

Although Stephens remained a disciple of Byrd in the 1950s-and was elected lieutenant governor with Byrd's support-he later broke with the Byrd Machine over school desegregation. A Guide to the Papers of A.E.S. Stephens, 1949-1961, VA. HERITAGE, http://ead. lib.virginia.edu/vivaxtf/view?docId=odu/vino00007.xml (last visited Mar. 19, 2012). Stephens ran for governor in 1961 without Byrd's support and easily lost the primary to Byrd's chosen candidate, Albertis S. Harrison. The race was seen as an indication that the Byrd Machine 
short, Lucy's lawyer was the man to whom Senator Byrd turned for counsel and to whom Virginia turned in its last stand to defend segregation. $^{44}$

Curiously sandwiched between fixing the Byrd Machine in 1952 and making Virginia's last stand in defense of segregation in 1958 was Harrison's involvement as the plaintiffs' lead attorney in Lucy $v$. Zehmer. These facts raise two important questions: Why did Lucy retain such a big name to argue such a small case, and why did Harrison accept the representation? Lucy's actions belie the cashstrapped buyer depicted in his own testimony and in the court's opinion, and, compared to the other statewide challenges that Harrison took on, a provincial liquor-induced dispute over a farm in southern Virginia seems downright pedestrian.

\section{B. The $\$ 50,000$ Question}

Questions about the motivations underlying Lucy v. Zehmer ultimately lead to questions about the disputed object-the Ferguson farm-and whether $\$ 50,000$ was really a fair price for the property. ${ }^{45}$ All too often, students and scholars overlook this question, and some casebooks omit the court's discussion of price altogether. ${ }^{46}$ Such an

remained a force in Virginia politics despite the political infighting of the 1950s. See Virginia: Byrd's Nest, Time, July 21, 1961, at 15 (reporting that "the primary did make one thing clear: if Harry Byrd is losing his grip, no one has told the voters of Virginia").

44. Saxon, supra note 38. Harrison reportedly had his doubts about Byrd's campaign of massive resistance, noting "in a letter to Byrd in August 1958 . . [that] admission of blacks to white schools probably was inevitable." Albertis Harrison, Governor 1962-66, supra note 42. But Harrison, the consummate attorney, was willing to fight hard to delay this inevitable result. As he wrote in a letter in July 1957 ,

Before this case was tried, I too had an idea, which I expressed to the Commission, that ... we could literally litigate negro plaintiffs to death and force them to exhaust administrative remedies. At that time, I envisioned appeals to the School Boards, then to the Circuit Court and then to our Supreme Court.

Letter from Senator A.S. Harrison Jr., to Hon. C. Harrison Mann Jr. 2 (July 27, 1957) (on file with the Duke Law Journal). Although Harrison was ultimately unsuccessful in preventing desegregation during his tenure as attorney general, his strategy did delay it. He succeeded, for example, in forcing the NAACP to refile a constitutional challenge against state laws designed to delay integration-which had been previously successfully litigated in federal court-in a substantially less favorable Virginia state court. See Harrison v. NAACP, 360 U.S. 167, 179 (1959) ("[T]he judgment below will be vacated and the case remanded to the District Court, with instructions to afford the appellees a reasonable opportunity to bring appropriate proceedings in the Virginia courts ....").

45. This was the first question asked by one local historian after his initial review of the case. Interview with Ronald Seagrave (Feb. 27, 2009).

46. See, e.g., AYRES \& SPEIDEL, supra note 2, at 229-32 (omitting the court's discussion of price); BURTON, supra note 2, at 11-15 (same); CALAMARI ET AL., supra note 2, at 1-7 (same); 
omission is not necessarily illogical. Both parties stipulated in their initial pleadings that a real-estate expert, C.C. Johnson, would, if called, testify that $\$ 50,000$ was a fair price for the Ferguson farm. ${ }^{47}$ Moreover, casebook authors most often rely upon Lucy v. Zehmer to demonstrate the main theory set forward by the court - the objective theory of contract formation-which dictates that one should look for objective signs of offer and acceptance rather than scrutinize the fairness of the transaction. ${ }^{48}$

An assessment of the fairness of the sales price was, however, central to the court's evaluation of Zehmer's equity claim, and Justice Buchanan relied on contextual evidence in determining that $\$ 50,000$ had been an objectively reasonable price for the farm. In rather sweeping language, Justice Buchanan denied the equity claim because "[t]he farm had been bought for $\$ 11,000$ and was assessed for taxation at $\$ 6,300$. The purchase price was $\$ 50,000$. Zehmer admitted that it was a good price." ${ }^{49}$ If anything, Justice Buchanan described the deal as a windfall for Zehmer.

But if the contract had truly created a windfall for Zehmer, why would Zehmer have invested so much in invalidating it, and, similarly, why would Lucy have tried so vigorously to enforce it? Although Justice Buchanan noted that Zehmer had expressed some interest in giving the farm to his son, the court's opinion does not explain why Zehmer had wanted his son to have the Ferguson farm in particular or why Zehmer could not, with his supposed windfall, have purchased a similar farm and pocketed the difference. ${ }^{50}$

There are other reasons to question Justice Buchanan's valuation even though it came directly from the record. First, Justice Buchanan only provided the historical price at which Zehmer had bought the farm and the property's tax assessment, neither of which is a reliable

Thomas D. Crandall \& Douglas J. Whaley, Cases, Problems, and Materials on CONTRACTS 1-7 (4th ed. 2004) (same); FARNSWORTH ET AL., supra note 2, at 117-20 (same); GEORGE W. KunEy \& ROBERT M. LlOYd, CONTRACTS: TRANSACTIONS AND LitigAtion $3-$ 10 (3d ed. 2011) (same).

47. Record, supra note 20, at 10 .

48. See, e.g., Solan, supra note 9, at 354-55 (summarizing the objective theory of contracts).

49. Lucy v. Zehmer, 84 S.E.2d 516, 522 (Va. 1954).

50. See id. at 520 (noting Zehmer's intention to give the farm to his son). The situation might have been different if the Ferguson farm had been in the Zehmer family for generations, but Zehmer had only acquired the property in 1943, Deed (1943), in 69 DINWIDDIE COUNTY DEED BOOK 167, 167, eleven years before the litigation commenced. 
indicator of the fair market value of real estate. ${ }^{51}$ At the same time, Justice Buchanan failed to include other relevant values, including Lucy's offers in 1944 and 1945 of $\$ 20,000$ for the same farm, only a year or so after Zehmer had purchased it for $\$ 11,000 .^{52}$ The court mentioned this fact in its discussion of enforceability but omitted the fact from its discussion of price. ${ }^{53}$

The mixed circumstantial evidence is enough to question whether Zehmer really did enjoy a windfall, or whether Lucy may in fact have been the party who received a bonanza profit. Nevertheless, Zehmer appears to have thought, at least at first, that $\$ 50,000$ was a good price for the farm. ${ }^{54}$ The price seemed so good, in fact, that

51. The $\$ 11,000$ price that Hardy Zehmer originally paid for the Ferguson farm was, in accounting terms, the farm's historical or “book value," see Vicki O. Tucker, Pattie G. Meire \& Phyllis M. Rubinstein, The RTC: A Practical Guide to the Receivership/Conservatorship Process and the Resolution of Failed Thrifts, 25 U. RICH. L. REV. 1, 17 n.74 (1990) (explaining that book value is generally historical value), but book values are generally regarded as unrealistic and unreliable, particularly for real-estate assets that appreciate over time, see Peta Spender, Guns and Greenmail: Fear and Loathing After Gambotto, 22 MeLB. U. L. REV. 96, 99-100 (1998) ("The book value of the land held by the company at the time of the meeting was $\$ 15,035,000$, but its market value was estimated to be $\$ 25,977,000$. It is therefore a reasonable assumption that the value of the assets held by the company was increasing."). Tax assessments-which rely on many factors unrelated to market prices-can be even more problematic. See William E. Banfield, Real Estate Taxes, in Negotiating the SophistiCATED REAL EsTATE DeAL 2008: High-Stakes Strategies in Challenging Times 215, 218 (PLI Real Estate Law \& Practice, Course Handbook Ser. No. 554, 2008) (noting that "value for real estate tax purposes is often different than value for other purposes . . . and in most cases it is very different from purchase price" (emphasis omitted)).

52. Record, supra note 20, at 2, 56 (referencing Deed, supra note 50, at 167).

53. Lucy, 84 S.E.2d at 518 (explaining that Zehmer similarly backed out of that alleged contract for the farm). Even Justice Buchanan's best argument for the price's fairness, that "Zehmer [had] admitted that $[\$ 50,000]$ was a good price," $i d$. at 522 , is questionable because the admission was arguably taken out of context. Zehmer made the statement at a Christmas party the day after the contract had been signed. It was an informal environment, and when Zehmer saw Lucy, he approached Lucy to tell him that they did not have a deal, even though he was "not trying to say this because . . . the price [was] too cheap." Record, supra note 20, at 38. Instead, Zehmer explained, "[I]f I wanted to sell, I think $\$ 50,000$ would be a good price, and I think you would get stuck." Id. (internal quotation mark omitted). How much research Zehmer had done before making this casual judgment about the price is unclear. This lack of familiarity with contemporary prices for land was similarly evident when Zehmer made clear in his deposition that he was not prepared to discuss prices. See id. at 33 (showing that Zehmer did not remember when he had bought the farm, how many acres the farm had included, or how much he had paid for the farm).

54. Record, supra note 20, at 44-45. During his deposition, Zehmer recalled having told Lucy the day after the alleged contract had been signed, "I am not trying to claim it wasn't a deal on account of the fact the price was too low . . . If I had wanted to sell $\$ 50,000.00$ would be a good price, in fact I think you would get stuck at $\$ 50,000.00$.” Id. (internal quotation marks omitted). 
Zehmer allegedly did not believe that Lucy was serious. ${ }^{55}$ Lucy, by contrast, must have felt that the price was a bargain that was worth pursuing through an expensive appeal. Clarifying the actual economics of the transaction may go a long way toward explaining the unusual banter that December evening.

\section{Alternative Narratives}

A number of dynamics are at play when an appellate court reverses a lower court's ruling, particularly when the reversal is as sweeping as the Virginia Supreme Court's rejection of Judge Jefferson's refusal to award Lucy the Ferguson farm. Many of these familiar dynamics, articulated by historians and legal scholars, appear to have been present in the trial and appellate proceedings in Lucy $v$. Zehmer and may explain the two courts' sharp disagreement as to how the case should have been decided.

One standard explanation is simple judicial politics. Harrison's extensive political activities on behalf of the Democratic Byrd Machine, ${ }^{56}$ including his role as a state senator on the senate committee that recommended candidates for judicial appointment, may have given Harrison influence over the justices on the Virginia Supreme Court $^{57}$-all of whom were Democrats or at least Democratic appointees. ${ }^{58}$ Zehmer, by contrast, was active in the state's Republican Party and served as an alternate delegate from Virginia to the Republican National Conventions in 1948, 1952, and $1956 .{ }^{59}$ Along these lines, one leading casebook speculates that "[a]pparently the Zehmers were infamous as being the only Republicans in this rural south side Virginia county during the era of the Byrd machine and were not 'well-liked." ${ }^{\prime 60}$ One must remember

55. See, e.g., id. at 38 ("I thought he was just needling me. I didn't think then [that] he considered it a deal.").

56. See supra notes $38-44$ and accompanying text.

57. See Letter from Senator A.S. Harrison Jr., to Hon. C. Harrison Mann Jr., supra note 44, at 1 (noting that Harrison was on the Senate Committee on Courts of Justice).

58. Governors of Virginia, ENCYCLOPEDIA VA., http://www.encyclopediavirginia.org/ Governors_of_Virginia (last updated Jan. 18, 2012) (listing all of the former governors of Virginia and showing that all of the governors from 1886 to 1970 were Democrats).

59. Lawrence Kestenbaum, Index to Politicians: Zealey to Ziegeweid, POL. GraveYARD, http://politicalgraveyard.com/bio/zebb-ziegenheim.html (last updated Dec. 12, 2011) (entry for Zehmer, A.H.).

60. SCOTT \& KRAUS, supra note 14, at 5 (quoting one of Professor Scott's students who was from Dinwiddie County). But Professors Scott and Kraus ultimately conclude: "While [the fact that the Zehmers were not well liked] might explain local prejudice against the Zehmers, it 
that the 1950s were a time when the Democratic and Republican parties were thoroughly consumed with fights over segregation and were bitterly divided in Virginia. Justice Buchanan also fits into this narrative: his vitriolic opinion in Naim v. Naim, ${ }^{61}$ which upheld the constitutionality of Virginia's antimiscegenation laws and which was issued only one year after Lucy v. Zehmer, suggests that his court may well have been hostile toward Republican litigants. ${ }^{62}$

Nonetheless, despite an exhaustive search, we have found little evidence that Zehmer would have been an obvious target of the Byrd Machine. In fact, Zehmer's lead defense counsel-Morton G. Goode-was also a prominent Democrat and state senator. ${ }^{63}$ The trial judge who initially dismissed the suit, Judge Jefferson Jr., was similarly active in local Democratic politics and was probably a

doesn't explain what happened here. The Zehmers won in the Dinwiddie circuit court. They lost at the Supreme Court in Richmond where presumably no one knew anyone." Id. There is reason to suspect, however, that politically motivated discrimination against Zehmer might have been more pronounced in Richmond than in Dinwiddie. The Virginia Supreme Court would have known Albertis S. Harrison Jr., the lead attorney for the plaintiffs. But Harrison, originally from Brunswick County, NEALE, supra note 41, at 288, might not have been as well known by the circuit court in neighboring Dinwiddie County as Zehmer's lawyers, see Lucy v. Zehmer, 84 S.E.2d 516, 517 (Va. 1954) (listing White and Goode as Zehmer's attorneys). who had both spent most of their careers as officers of that court, see, e.g., Deed (1938), in 62 DINWIDDIE COUNTY DEED BOOK 600, 600 (noting that White was a special commissioner in the court). Accordingly, a political explanation might suggest that Zehmer won in the local forum, where his local counsel were better known, and Lucy subsequently won in the state capital, where his lead attorney was a rising star.

61. Naim v. Naim, 87 S.E.2d 749 (Va. 1955).

62. Justice Buchanan's opinion concludes,

We are unable to read in the Fourteenth Amendment to the Constitution, or in any other provision of that great document, any words or any intendment which prohibit the State from enacting legislation to preserve the racial integrity of its citizens, or which denies the power of the State to regulate the marriage relation so that it shall not have a mongrel breed of citizens. We find there no requirement that the State shall not legislate to prevent the obliteration of racial pride, but must permit the corruption of blood even though it weaken or destroy the quality of its citizenship. Both sacred and secular history teach that nations and races have better advanced in human progress when they cultivated their own distinctive characteristics and culture and developed their own peculiar genius.

Id. at 756 .

63. See Council of State Gov'Ts, Book of THE States 1952-1953, at 559 (1952) (listing Morton G. Goode as the president pro tem of the Virginia state senate-a body composed of thirty-eight Democrats and two Republicans at the time); A Guide to the Harry Flood Byrd, Sr. Papers, VA. HerITAGE, http://ead.lib.virginia.edu/vivaxtf/view?docId=uva-sc/ viu01045.xml (last visited Mar. 19, 2012) (referencing an array of correspondence sent between Senator Byrd and M.G. Goode between 1923 and 1948). 
member of the Byrd Machine. ${ }^{64}$ These facts undermine the supposition that Zehmer was somehow the victim of politicized Democrats in Richmond.

A second explanation rests on the different policy priorities of the trial and appellate judges. By the time Lucy filed for an injunction in his courtroom, Judge Jefferson was an established jurist with a law degree from the University of Virginia and nearly twenty years on the bench. ${ }^{65}$ A descendant of prominent colonial families on both parental lines and, reportedly, an enthusiastic farmer ${ }^{66}$ Judge Jefferson was likely to attribute deep and perhaps romantic significance to a farmer's connection to his family farm and might have resisted swift, potentially spontaneous, and loosely documented land sales. Agrarian life enjoyed a glorified status in Virginia society, as many of Virginia's legendary family dynasties were linked to ownership of substantial rural estates, ${ }^{67}$ and Virginia culture held up agrarian ideals, even after industrialization started dominating the twentieth-century Southern economy. ${ }^{68}$

The state supreme court in Richmond, by contrast, may have been more concerned with the demands of modern commerce, including the alienability of property. Scholars have recognized that state supreme courts were very policy oriented, as opposed to formalistic, when articulating contract law and, especially, when adjudicating land disputes. ${ }^{69}$ Even while local courts were sensitive to

64. Virginia LiVes: The Old Dominion Who's Who 507 (Richard Lee Morton ed., 1964) ("A member of the Democratic Party, Mr. Jefferson served as Chairman of the Amelia Democratic Committee.").

65. See id. ("John G. Jefferson, Jr., attended . . . the University of Virginia, from which he received his Bachelor of Laws degree in 1908. Engaged in a private law practice from 1908 to 1938, Mr. Jefferson served as Trial Justice of Amelia and Powhatan Counties from 1934 to 1938, and as Judge of the Fourth Judicial Circuit from 1938 until his retirement on August 31, 1962.”).

66. Id.

67. See infra notes $84-85$ and accompanying text.

68. See generally Twelve Southerners, I'Ll TAKe My StAnd: The South AND THE AgRARIAN TRADITION (1930) (discussing agrarian idealism and its devoted resistance to industrialization across the South); PAUl V. MurPhy, THE REBUKE of History: The SOUTHERn AGRARIANS AND AMERICAN CONSERVATIVE THOUGHT 67-68 (2001) (describing a debate in Richmond, attended by 3500 people, on the clash of agrarian ideals against industrialism); Wayne Mixon, Resistance to Industrialization, in THE ENCYCLOPEDIA OF SOUTHERN CUlTURE 724, 724-26 (Charles Reagan Wilson \& William Ferris eds., 1989) (discussing the depth of agrarian attitudes and the impact of both the publication of I'LL TAKE MY STAND, supra, and the agrarian literary movement from the Civil War to the early 1970s).

69. See LaWrence M. Friedman, Contract Law in America 33-34 (1965) (discussing the Wisconsin Supreme Court's treatment of land transactions between 1826 and 1861 and 
personal and historical attachments to land, appellate courts - in part deliberately aiming to contrast American alienability with feudal systems - were deliberately supportive of enforcing land sales and encouraging the acquisition of land for commercial development. ${ }^{70}$ More broadly, American law during and following the New Deal challenged persistent notions of social hierarchy and expanded the even-handed enforcement of contract and property rights. ${ }^{71}$ This move toward modernity further greased the wheels of rapid commerce and enhanced the alienability of property, including family farms.

The Lucy opinion appears to have been part of this trend. As Virginia's economy became more industrial during the $1950 \mathrm{~s},{ }^{72}$ nationwide legal reforms that were designed to facilitate commercial dealings and the predictability of contractual rights had an acute effect in Virginia. The Uniform Commercial Code was introduced for the first time to eight state legislatures in the $1950 \mathrm{~s},{ }^{73}$ and Virginia was pursuing reforms of its own commercial code. ${ }^{74}$ Legal reforms designed to facilitate commercial transactions would have been a much higher priority for the state supreme court than for a regional judge - or an avid farmer-in rural Dinwiddie County.

Judge Jefferson might also contribute to yet another narrative that has gained attention among legal historians. Judge Jefferson's dismissive rejection of Lucy's claims may have simply been the product of a deeply rooted Southern tradition in which local judges, less concerned about uniform legal principles, assumed the role of

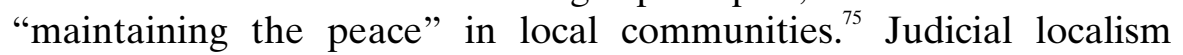

noting that the "judicial attitude toward land cases was ... strongly colored by considerations of public policy" and that "the court examined [the existing legal] system with a critical eye").

70. See id. at 28-29 (describing the Wisconsin Supreme Court's attitude toward land transactions during the same time period).

71. Lawrence Friedman, American Law in the Twentieth Century 384-85 (2002).

72. See Southside Study Comm., Advisory Council on the Va. Econ., A Survey of the ECONOMic Potential of SiX Southside Virginia Counties 51-55 (1960) (summarizing the growth in manufacturing during the 1940s and 1950s).

73. William A. Schnader, A Short History of the Preparation and Enactment of the Uniform Commercial Code, 22 U. Miami L. Rev. 1, 8 (1967).

74. See, e.g., George D. Gibson \& George C. Freeman, Jr., A Decade of the Model Business Corporation Act in Virginia, 53 VA. L. REV. 1396, 1396-98 (1967) (describing efforts to modernize and codify Virginia corporation law).

75. See, e.g., Laura F. Edwards, The People and Their Peace: Legal Culture AND THE TRANSFORMATION OF INEQUALITY IN THE POST-REVOlUTIONARY SOUTH 4 (2009) 
rested on a loose set of power dynamics and a rough sense of justice that "allow[ed] local custom, politics, and law to mingle freely" ${ }^{\text {"76 }}$ and in which "judgments rested on the situated knowledge of observers in local communities [largely] through family and neighborly ties and continually assessed through gossip networks." Southern law was not a technical enterprise and instead "depended on information conveyed orally by ordinary people," with written materials serving a secondary role "as a reminder of oral knowledge that had determined the process." $" 18$

Like much of southeast Virginia, Dinwiddie County_for many of the reasons discussed in the next Sections-was having more than its fair share of land disputes, ${ }^{79}$ and Judge Jefferson was likely alarmed by the litigation and unseemly contracting practices that had found their way into his and other courtrooms. His priority, like many other local Southern judges, might have been chiefly to maintain the stable status quo. ${ }^{80}$ Judge Jefferson's terse ruling, lack of legal analysis, and sparse justification for maintaining the status quo all match the concept of "local peace" in both substance and style.

(describing the development of this tradition of localism in the Carolinas during the antebellum period).

76. Id. at 5 .

77. Id. at 7 .

78. Id. at 4 .

79. For a discussion of the significant experience thrust upon southern Virginia's judges in adjudicating land disputes, see infra Part III.D.

80. EDWARDS, supra note 75, at 7 ("Keeping the peace meant keeping everyone-from the lowest to the highest-in their appropriate places, as defined in specific local contexts. Local courts focused on the resolution of these highly personal, idiosyncratic disputes."). Substantial evidence suggests that local judges and court officials were intimately familiar with the litigants who appeared in their chambers-and the gossip accompanying their disputes. Id. at 7-8. Welford Lucy, Hardy Zehmer, and Hardy Zehmer's wife, for example, very publicly discussed the alleged contract with neighbors - and each other-the day after the contract was signed. These discussions took place, of all places, at a house party hosted by the "brother of the [Dinwiddie County] Clerk of the Court." Record, supra note 20, at 26-27, 37-38. A few days later, Zehmer argued with Lucy again about the contract, a conversation that occurred "in the presence of Judge Barrow." Record, supra note 20, at 38. Judge B. Hunter Barrow was a county judge in Dinwiddie between 1934 and 1970. JONES, supra note 18, at 184.

81. Professor Laura Edwards's description of social stability within a stable and familiar community of actors, see, e.g., EDWARDS, supra note 75, at 7-8, relates to what economists might describe as the sustained benefits from continued reciprocity. The local institutions that promoted reciprocity in the South were similar to the extralegal mechanisms that early law-andsociety scholars credit for maintaining stable commercial relationships, see Mark Galanter, Justice in Many Rooms: Courts, Private Ordering and Indigenous Law, 19 J. LEGAL PLURALISM 1, 24 (1981); Stewart Macaulay, Non-Contractual Relations in Business: A Preliminary Study, 28 AMER. SOC. REV. 55, 63 (1963); to what game theorists modeled as self-sustaining cooperation, 
This appearance of localism in Judge Jefferson's ruling could be precisely what led to a sharp rebuke from Justice Buchanan. The Virginia Supreme Court, like other statewide bodies, likely "aspired to create a unified body of law and a centralized institutional structure to enforce it." ${ }^{, 82}$ Lucy $v$. Zehmer was tried at a time when advocates of unified notions of law were seeking to limit the inconsistency and discretion inherent in decentralized notions of justice. The Uniform Commercial Code, for example, was attracting considerable attention from state courts and legislatures at that time, in large part because it aimed to "relegate local tradition, prejudice and provincialism to a position secondary to clarity, simplification, standardization and uniformity of the laws." ${ }^{, 83}$ Appellate courts often imposed principles of law precisely to counter local preferences for societal stability.

Although each of these narratives is independently capable of providing a meaningful and revealing new perspective on the story of Lucy v. Zehmer, our preferred narrative is more economic in nature. We report that Lucy v. Zehmer took place within a rapidly changing economic climate that heightened the economic incentives to acquire land. Such opportunities to profit quickly from land encouraged transactions that both created economic upheaval and facilitated dramatic economic transition. The Lucy brothers played active roles in this industrial transformation, and our inclination toward an economic narrative is guided significantly by our early discovery that Welford Lucy was a shrewd and aggressive businessman who, reflecting his era, capitalized on an economy in transition and social roles in flux.

see Robert Axelrod, The Evolution of COOPERATIOn 118-20 (1984); and to what some economic historians and institutionalists attributed to the efficacy of prelegal reputation mechanisms, see Avner Grief, Contract Enforceability and Economic Institutions in Early Trade: The Maghribi Traders' Coalition, 83 AM. ECON. REV. 525, 525-48 (1993); Paul Milgrom, Doug North \& Barry Weingast, The Role of Institutions in the Revival of Trade: The Law Merchant, Private Judges, and the Champaign Fairs, 2 ECON. \& POL. 1, 1-2 (1990).

82. EDWARDS, supra note 75 , at 4.

83. Samuel A. Dew, The Urge for Uniformity in State Laws, 20 U. KAN. CITY L. REV. 56, 62 (1952). 


\section{THE FARMER AND THE LUMBERMAN}

Some Southern aristocrats, like the Harrisons, could trace the ownership of their lands to a royal charter.$^{84}$ Others, like the dynasty founded by Harry F. Byrd, rose to political and social prominence through the wise acquisition and management of local lands. ${ }^{85}$ The Zehmers of Dinwiddie County fell somewhere in between.

At the time of the dispute in Lucy v. Zehmer, the Zehmers had been a prominent fixture in Dinwiddie County for more than a century. The dynasty began with Captain Charles Zehmer, a DutchGerman merchant from Philadelphia who was reportedly a member of elite circles during colonial times. ${ }^{86}$ In addition to a fleet of ships, Captain Zehmer owned a plantation, a tanning business, and extensive land holdings in Virginia and Pennsylvania. ${ }^{87}$ Upon his death, Captain Zehmer left all of his property to his sole heir, a son named Charles Grandison Zehmer, who subsequently lost the entire estate in a game of cards. ${ }^{88}$ Charles Grandison later attended medical school and returned to his native Dinwiddie County to become a local physician. ${ }^{89}$ There Dr. Zehmer raised eleven children, whose descendants prospered in Dinwiddie County for more than a century. ${ }^{90}$ As their prominence grew over time, so did their holdings of land. ${ }^{91}$

The history of the Zehmer family is very much the history of McKenney, the small town in Dinwiddie County where the Zehmers

84. See Saxon, supra note 38 (noting that Albertis S. Harrison's "home sat on a tract deeded to an ancestor, Henry Harrison, by King George II in 1732").

85. See, e.g., Harry F. Byrd (1887-1966), ENCYCLOPEDIA VA., http://www.encyclopedia virginia.org/Byrd_Harry_Flood_Sr_1887-1966 (last updated Apr. 7, 2011). Byrd also came from an established family of colonial fame, but his purchase and efficient management of apple orchards paved the way for his rise to decades-long dominance in Virginia's political system. Id.

86. Roberta Zehmer Smith, Zehmer: A FAmily History 2-3 (Jane C. Arnett ed., 1984).

87. Id. at $2-4$.

88. Id. at 3-4, 13. Charles Grandison Zehmer reportedly only bet his life-estate rights on the card game, but the property was never returned to the family after his death. Id. at 13-14.

89. Id. at 14 .

90. Id. at $14-16$.

91. See, e.g., JOHN G. ZEHMER, JR., NATIONAL Register OF HistoriC Places REGISTRATION FORM: ZEHMER FARM, DHR NO. 257-5008, § 8, at 10 (2009) (describing the family's acquisitions of various properties in the McKenney area). Members of the Zehmer family are listed as grantees on 386 separate land deeds in Dinwiddie County dated between the years 1847 and 1986. 
lived. Named after William Robertson McKenney, ${ }^{92}$ a railroad attorney from Richmond, ${ }^{93}$ McKenney was founded around 1900 when the railroad was built to connect the isolated and rural south of Dinwiddie County to the Richmond market to the north. ${ }^{94}$ Many local institutions, such as the local bank, were established during this period to meet the sudden demand generated by this growing commercial link. ${ }^{95}$ Among these institutions were several businesses established by the Zehmer family, ${ }^{96}$ businesses that cemented the Zehmers' influence in the town.

At first, the Zehmers established a sawmill business to cut lumber for railroad ties, and, as the railroad pushed deeper into Dinwiddie, the Zehmers purchased vast tracts of timberland to keep up with the railroad's needs. ${ }^{97}$ With a sawmill small enough to move from tract to tract, the Zehmers acquired heavily forested properties to harvest timber and moved their mill quickly from one property to the next. ${ }^{98}$ This process led the Zehmers to acquire substantial land holdings around the outskirts of what became McKenney, solidifying their influence as a prominent family in the small town. ${ }^{99}$

This business had a natural limit, and the family looked to use its land holdings for alternative businesses once the local railroad line had been established. In the 1920s, the family began to farm tobacco, ${ }^{100}$ a profitable cash crop at the time. ${ }^{101}$ Less than twenty years later, they supplemented their income by raising cattle, a business that was naturally followed by dairy farming. ${ }^{102}$ As each business

92. McKenney was a University of Virginia law graduate and former congressman from Petersburg. See McKenney, William Robertson (1851-1916), BIOGRAPHICAL DIRECTORY OF THE U.S. CONGRESS, http://bioguide.congress.gov/scripts/biodisplay.pl?index=M000502 (last visited Mar. 19, 2012) (providing biographical information about McKenney).

93. See Our First 100 Years, BANK OF MCKENNEY, http://www.bankofmckenney.com/index .php?option=com_content\&view=article\&id=46\&Itemid=54 (last visited Mar. 19, 2012) (noting that McKenney was an attorney for various railroads).

94. Id.

95. Id.

96. See generally ZEHMER, supra note 91 (listing the businesses established by the Zehmers).

97. Id. $\S 8$, at 10-11 (recording the expansion of the Zehmer farm).

98. See id. $\S 8$, at 11 (noting that there were numerous sawmill sites on the farm).

99. See id. $\$ 8$, at 10-11 (recording increased acquisitions).

100. See id. $\S 7$, at 7. ("Two log, flue-cured tobacco barns, built around 1920, stand near the main entrance ....").

101. See id. $\S 8$, at 12 ("[T] he primary farming enterprise on the farm was tobacco as a cash crop ....").

102. Id. $\$ 8$, at 13 . 
reached what seemed like its natural limit, other family businesses were established, including a local grocery store, a local hardware store, ${ }^{103}$ and, ultimately, Ye Olde Virginnie, the small "tourist court" operated by Hardy Zehmer. ${ }^{104}$

\section{Image 1. Hardy Zehmer's Tourist Court ${ }^{105}$}

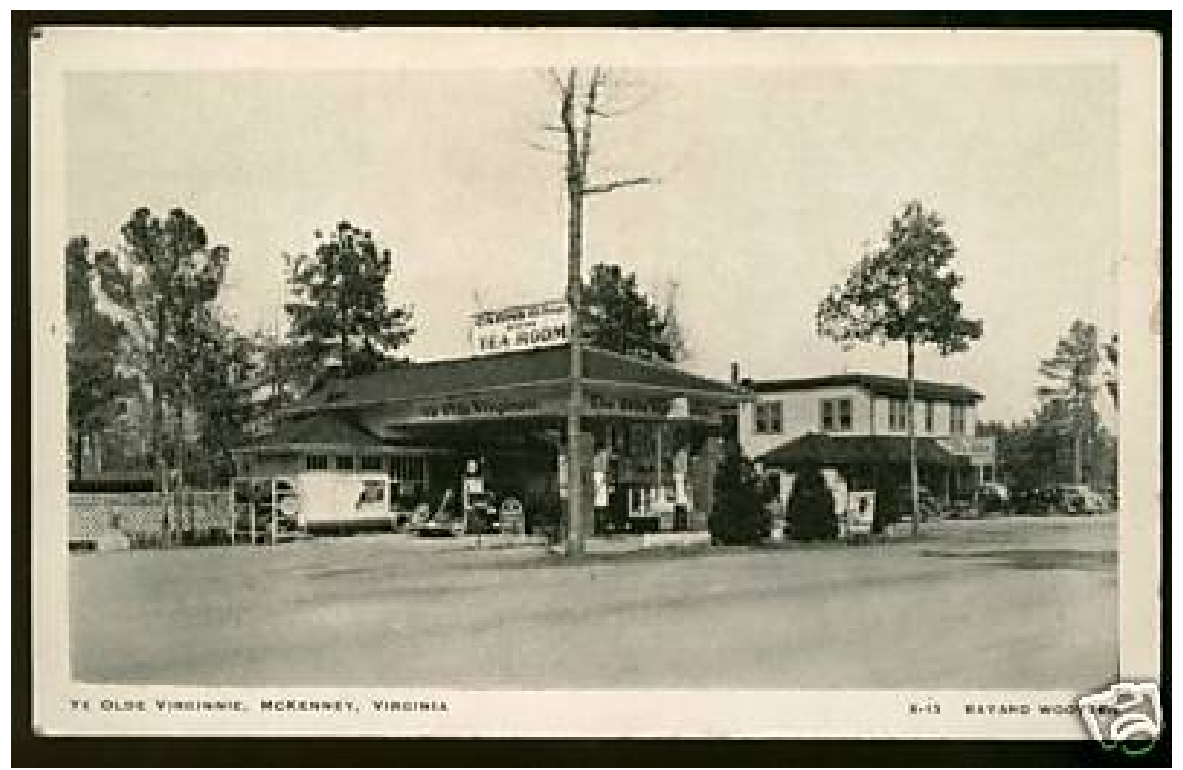

Hardy Zehmer was a farmer born into a well-landed farming family, but he also was an educated businessman, attending southern Virginia's prestigious Hampden-Sydney College ${ }^{106}$ and then briefly working for E. I. du Pont de Nemours as the foreman of a munitions plant during World War I. ${ }^{107}$ After the war, Zehmer returned to

103. Id. $\$ 8$, at 11 .

104. See Ye Olde Virginnie, The One Stop Tourist Court (on file with the Duke Law Journal). A postcard uncovered by Professor Frank Snyder describes the business as "The One Stop Motel" in McKenney, Virginia, with "Individual and Family-type rooms-Air conditioned-Steam Heat-Television-Restaurant-Service Station-Garage." See Frank Snyder, Carry Me Back to Ye Olde Virginnie, CONTRACTS PROF BlOG (Feb. 15, 2008), http:// lawprofessors.typepad.com/contractsprof_blog/2008/02/carry-me-back-t.html.

105. Photograph provided by Ronald Seagrave. Original source unknown.

106. Both Justice Buchanan and Judge Jefferson attended Hampden-Sydney College. See VIRGINIA LIVES, supra note 64, at 132.

107. See Adrian Hardy Zehmer, Registration Card No. 4107 (1917) (on file with the Duke Law Journal) (recording Zehmer's place of employment). At the time, the large gun cotton 
conduct business in his native McKenney, where he quickly established a restaurant, service station, motel, and guest cabins. ${ }^{108}$ These assorted business ventures primarily catered to travelers along Highway 1, the main north-south thoroughfare connecting Maine to Florida at the time, and were profitable even during the Depression, when so many other local businesses failed. As a measure of his success, Zehmer, in a period when many were losing their farms, had enough disposable income to buy the Ferguson farm, a property that Zehmer had no desire to operate for commercial purposes. ${ }^{109}$

In spite, or perhaps because, of Zehmer's wealth, he had a lessthan-sterling reputation among McKenney's residents and is remembered as having been a colorful character. As one neighbor recounted, Zehmer was known for his drinking even before that fateful December evening in 1952 and had had several reported runins with state and local officials. ${ }^{110} \mathrm{He}$ also was the town's leading Republican in an age in which most town residents may still have thought of the Republican Party as the party of Presidents Lincoln and Hoover. The reasons for Zehmer's political allegiances are not entirely clear, but his politics made Zehmer a relative outcast in town despite the prominence of his family. This disaffection was evidently mutual: Hardy and Ida Zehmer evidently did not consider themselves to be "McKenney people," reportedly felt a similar distance from the Zehmers. ${ }^{112}$ Perhaps one

factory in Hopewell "employed almost all of the employable labor in that area." Hercules Powder Co. v. Cont'l Can Co., 86 S.E.2d 128, 129 (Va. 1955).

108. Snyder, supra note 104.

109. See Record, supra note 20, at 24, 41 (providing Ida and Hardy Zehmer's deposition testimony that, at most, several cows had been kept on the farm). A member of the Zehmer family also confirmed Hardy Zehmer's wealth and that he had held the farm as an investment rather than as an active business asset. Telephone Interview with a Zehmer Family Member (Nov. 23, 2010).

110. Interview with Floyd M. Harrison Jr., in Dinwiddie Cnty., Va. (Oct. 15, 2009) (recounting stories about times Zehmer's liquor license had been suspended for excessive drinking behind the bar and a time Zehmer, while visiting a friend who called out the local fire department, supposedly told the arriving firemen that "the fire [was] in [his] belly").

111. Record, supra note 20, at 27 (“[W]e are out of the corporate limits, and I don't have too much contact with McKenney people." (quoting Ida Zehmer)).

112. See SCOTT \& KRAUS, supra note 14, at 5 (reporting that the Zehmers "were not "wellliked" in their community (quoting one of Professor Scott's students who was from Dinwiddie County)). 
should not be surprised then that Zehmer primarily directed his businesses toward those only passing through town. ${ }^{113}$

The Lucy brothers came from a world far away from the Zehmers' privilege. Though also born into a farming family-their father ran a tobacco farm - the Lucy brothers lost everything when their father's farm went bankrupt in the early years of the Depression; and the five Lucy children were left to fend for themselves. ${ }^{114}$ John Cleveland Lucy, Welford's older brother and a coplaintiff, never finished the seventh grade and went to work in the lumber industry as a teenager. ${ }^{115}$ Eventually scraping together enough money to buy a small sawmill, John enjoyed the freedom that came from running his own business, even though he took on an occasional partner on larger projects. ${ }^{116}$

In his early years, John bought and cut timber from the land of local farmers, financing the purchases with loans and then selling the cut timber to local lumber companies at a profit. From the start, he relied on one institution in particular-the Farmers and Merchants Bank-to finance most of his activities. His agreements with that bank were in turn drawn up by the bank's attorney and one of its trustees at the time, a young commonwealth attorney named Albertis S. Harrison Jr. ${ }^{117}$ The bank's trust in John's business grew over time, as evidenced by the large number of loans it issued to Lucy and his

113. Whatever the reasons for this mutual distaste, whether it was shared by the Lucy brothers is unclear. Indeed, John C. Lucy Jr., the son of coplaintiff John C. Lucy, fondly remembers dining at Zehmer's restaurant as a child and thinking of Hardy Zehmer as "a very pleasant man.” Interview with John C. Lucy Jr., John C. Lucy III, and James Lucy, in Durham, N.C. (July 16, 2009). If the Lucy brothers personally disliked Hardy Zehmer, such feelings were not voiced to the rest of their family, leaving the ironic possibility that, at least on the surface, the Lucy brothers might have been among the few in the area with a positive view of Hardy Zehmer.

114. Id.

115. Id.

116. See Email from John C. Lucy III to author (Feb. 17, 2011, 12:56 AM) (on file with the Duke Law Journal) (containing comments from Emory Lucy explaining that the "vast majority of [John C. Lucy's] dealings were done on his own" but naming Clyde Delbridge and Shorty Jones as two business partners).

117. A commonwealth attorney is the local equivalent of a district attorney in Virginia. See BUREAU OF MUN. RESEARCH, RICHMOND, VIRGINIA: REPORT ON A SURVEY OF THE CITY GOVERNMENT 455 (1917) (stating that the commonwealth attorney was "the prosecuting officer of the City of Richmond"). Over the course of his career, Harrison continued to serve as a trustee for the Farmers and Merchants Bank. Indeed, his name is listed as trustee on so many trust deeds that Brunswick County has an entire Grantee Deed Index just for the Harrison family. The Grantee Deed Index is on file with the Duke Law Journal. 
brothers over the next two decades. ${ }^{118}$ For many years, John even sat on the bank's board along with Harrison. ${ }^{119}$

Welford, unlike his brother, was not content remaining in his native Brunswick County. Instead, he looked further north to neighboring Dinwiddie County, at first driving a truck for a local businessman and then getting into lumber and cattle farming. ${ }^{120}$ In the 1940s, he purchased an estate along Highway 1, not too far from Zehmer's tourist court. ${ }^{121}$ This change marked the first time, but not the last time, that Welford would feel the need to move to a new community to pursue new business opportunities. ${ }^{122}$

Welford arrived in McKenney as an outsider, and although he would become a close associate of several residents-including Harrison Zehmer, a cousin of Hardy Zehmer who would often spend his evenings at Hardy's restaurant ${ }^{123}$-views vary as to whether Welford ever integrated himself into the area. Some residents recall that Lucy was known to be shady with his business and that-like many of the county's lumbermen at the time ${ }^{124}$-he was eager to make

118. At the same time, Emory Lucy, one of John C. Lucy's sons, insists that tracking his father's timber-cutting business just by tracking these loans would be difficult. Instead, he believes that his father usually paid for timber to be harvested in cash and only took loans when absolutely necessary. Interview with Emory Lucy, in Brunswick Cnty., Va. (Oct. 27, 2009).

119. Despite his humble roots, John C. Lucy saw himself as a gentleman. When heading out to work in the field, John always wore a full suit, complete with a bow tie. Interview with John C. Lucy Jr., John C. Lucy III, and James Lucy, supra note 113. As one of his sons recalls, he even wore the suit for breakfast. Id. Beyond business at the bank, John C. Lucy also developed a close bond with Albertis S. Harrison. Id. Although the poorly educated businessman might seem a strange match with the well-educated lawyer, John's descendants recall that the two men were close personal friends. Id. The two regularly played golf together, and John C. Lucy in particular was a true believer in Harrison and his political skill. Id. Emory Lucy, one of John's sons (who had served as a driver for Harrison during one of his early political campaigns), recalls that his father sagely predicted that Harrison would be elected governor long before Harrison's victory in 1962. Interview with Emory Lucy, supra note 118. A loyal Democrat, Welford was similarly supportive of Harrison's political ambitions. Welford's Dinwiddie farm had a large barbeque pit with picnic tables where he hosted political fundraisers for Harrison during each election season. Interview with Meade Lucy, in Durham, N.C. (Dec. 10, 2010).

120. Interview with Meade Lucy, supra note 119.

121. Id.

122. See infra Postscript.

123. Interview with Floyd M. Harrison Jr., supra note 110.

124. Although Justice Buchanan described Lucy as a "lumberman and farmer," Lucy v. Zehmer, 84 S.E.2d 516, 518 (Va. 1954), Lucy's actual deposition testimony emphasized his lumber business, only including "some farming" as though it was an afterthought, Record, supra note 20 , at 51 . 
quick profits off of the land of others. ${ }^{125}$

Although Hardy Zehmer may have prided himself on his superior education and business acumen, the region's economic changes were being driven by market forces that extended far beyond Zehmer's tourist court. As we discuss in the next Part, these economic changes created new profit opportunities for the undereducated but enterprising Lucy brothers, who, despite starting with only a small mill, played a significant role in the timber economies of Dinwiddie and Brunswick Counties during a period of significant industrial expansion.

\section{TIMBER PRICES, LAND DISPUTES, AND AN INDUSTRIAL SHIFT IN THE SOUTH}

When John C. Lucy began his career as a lumberman in the 1930s, economic trends that had begun in the 1920s and that had accelerated throughout the 1950s were rapidly changing the business of lumbermen across the American South. During much of this period, the lumber industry of southern Virginia-the region's traditional driver of prices for raw-timber resources ${ }^{126}$ - was waning in the face of declining demand for southern pine. ${ }^{127}$ Yet far from

125. When asked, for instance, whether Welford's reputation was hurt by the dispute in Lucy v. Zehmer, one neighbor-Floyd M. Harrison Jr.-responded with a bluntness characteristic of Dinwiddie residents: "What reputation?" Interview with Floyd M. Harrison Jr., supra note 110. Welford's youngest son, Meade Lucy, saw a different side to his father, describing Welford as a complicated man who was strict and a bit distant at home but friendly and outgoing with most people in the community. Interview with Meade Lucy, supra note 119. As his son recalls, Welford was the kind of person who "never met a stranger." Id.

126. In forestry, "timber" is the raw tree that is harvested. See BLACK's LAW DiCTIONARY 1172 (1st ed. 1891) (defining "timber" as "[w]ood felled for building or other such use"). Trees in the field are often referred to as "standing timber." See, e.g., Roberts v. Nevel, 140 S.E. 557, 559 (Va. 1927) (interpreting a contract that used the phrase "standing timber"). "Lumber," by contrast, is a finished product intended for use by an end consumer, such as in the term "lumber boards." See, e.g., id. (explaining the "clear and definite" technical definition of the term "lumber" as distinct from the "loose, inaccurate verbiage of the layman"). Although lumber was the main product made from timber in the South, making other products (such as "wood pulp") is possible as well. See 7 JOHN GRIMES WALKER, REPORT ON THE ISTHMIAN CANAL COMMISSION, 1899-1901, at 522-23 (1904) (noting that the Southern states "furnish[ed] more than half of the lumber exported from the United States" but that wood-pulp mills were "mostly located in the northeastern part of the United States"). "Wood pulp," in turn, can be used to produce paper. $I d$. at 522 .

127. See, e.g., I. James Pikl, Jr., Southern Forest-Products and Forestry: Developments and Prospects, 42 J. FARM ECON. 268, 269-71 (1960) (describing the decline in "[1]arge-scale lumbering operations" in the South from 1909 to 1958 and the declining demand for southern pine due to complaints about its quality). 
slowing down, business was heating up for lumbermen in the region, as industrial leaders addressed weak markets for lumber by investing heavily in plants to make wood pulp, a valuable raw material used to produce paper. ${ }^{128}$ The new capacity for paper manufacturing made harvesting timber for wood pulp quite lucrative, which in turn created a shock to local timber prices. ${ }^{129}$ Demand for timber spiked as companies sought to acquire more timberlands to guarantee their timber supplies, and speculation over timberlands spread. ${ }^{130}$ This economic boom provides the context essential to understanding the 1952 encounter in Zehmer's restaurant. ${ }^{131}$

\section{A. When the Farmer Met the Lumberman: Timber's Early Years}

The lumber industry has deep roots in southern Virginia, dating back to at least $1855 .{ }^{132}$ Home to many dense forests-and good soil for quickly growing pine forests-southern Virginia was a natural attraction for lumbermen. ${ }^{133}$ Whereas early sawmills were isolated outposts in an agrarian economy dominated by tobacco plantations, the Civil War soon transformed the lumber industry into a more powerful force. After the war, farmers devastated by the collapse of tobacco and cotton prices were desperate to recover some value from effectively defunct family farms and plantation lands. Although timberlands were valueless to Southern farmers, Northern lumbermen had the machinery and the know-how to harvest and bring timber to market. ${ }^{134}$ Native Virginians soon took to the lumber industry as well, realizing that they could pay only a pittance for

128. See id. at 272 (describing how pulp-and-paper products were displacing lumber interests in the South).

129. See infra Part III.B.

130. See infra Part III.B.

131. See infra Part IV.

132. See PARke Rouse JR., The Timber Tycoons: The CAMP FAMILIES of VirginiA AND FLORIDA AND THEIR EMPIRE 1887-1987, at 31 (1988) ("[T]he largest and most desirable sawmill in southern Virginia . . . was . . owned by the brothers R. J. and William Neely, formerly of Pennsylvania. It had been started in 1855 by John Frisbee and had shipped lumber as far as Düsseldorf and Hamburg.").

133. See id. at 35 ("Nowhere in the world did pine grow better than in the sandy region south of the James River in Virginia, beginning at Richmond and extending southward to the Neuse River in North Carolina.").

134. See id. at 29 ("To meet the demand for timber, a wave of Northern sawmill operators had swept into Virginia after 1865. With forest lands selling for as little as $\$ 5$ an acre, venturers set up many sawmills and began to produce both rough-hewn and finished lumber."). 
woodlands and then earn back the purchase price after the first harvest of timber. ${ }^{135}$

"As a rule," the circuit court of Brunswick County later wrote, "the farmer welcomed the lumberman, who came to buy something which, heretofore had never been convertible into ready cash."136 Faced with willing sellers of "immense quantities of timber," lumbermen proceeded "to erect large and expensive plants and to build railroads into the territory where the timber stood." few decades, the local lumber industry was recognized as "one of the most important industries of Virginia and of the South." "138

Investments in extracting southern pine for lumber also paved the way for follow-on industries that similarly relied on harvesting southern pine, including the important paper-and-pulp industry. Paper production began in the South as early as 1878 , when the Marietta Paper Manufacturing Company of Georgia demonstrated that paper could be produced from southern pine, ${ }^{139}$ and in 1891 the Carolina Fibre Company of South Carolina went one step further by proving that manufacturing paper from southern-pine wood pulp could be commercially viable. ${ }^{140}$ Although these two plants stood largely alone for several decades, pulp-and-paper plants had been built across the region by the $1920 \mathrm{~s}^{141}$ The lumbermen of Virginia assumed a leading role in these developments, ${ }^{142}$ and by 1927, Virginia companies led the South in annual paper output. ${ }^{143}$

135. See id. at 36 ("[Paul Camp of the Camp Manufacturing Company] bought [land] for as little as $\$ 5$ and $\$ 10$ an acre, often repaying the land costs by the sale of its first timber.").

136. Camp Mfg. Co. v. Young, 14 Va. L. Reg. 89, 99 (Va. Cir. Ct. 1908), rev'd in part, 66 S.E. 843 (Va. 1910).

137. Id.

138. Id.

139. H.J. Malsberger, The Pulp and Paper Industry in the South, 54 J. FORESTRY 639, 639

(1956).

140. Id.

141. D.H. Killeffer, Paper Goes South, 30 Indus. \& ENGINEERING CHEMISTRY 1110, 1111 (1938)

142. See, e.g., Diana Twede \& Susan E.M. Selke, Cartons, Crates, AND CORRugated BoARd: HANDBOOK OF PAPER AND WOOD PACKAgING TECHNOLOGy 58 (2005) (noting that the plant established by the Hummel-Ross Fibre Company in Hopewell began producing kraft linerboard commercially in 1923); Lauren B. Hitchcock, Cellulose in Virginia: I-Pulp and Paper, 22 Indus. \& ENGINEERING CHEMISTRY 488, 489 (1930) (referencing a plant jointly operated by the John H. Heald Company and the Mead Paperboard Company in Lynchburg that, shortly before 1930, had expanded into the paper industry); Chesapeake Corporation, FUNDING UNIVERSE, http://www.fundinguniverse.com/companyhistories/Chesapeake-Corporation-Company-History.html (last visited Mar. 19, 2012) 


\section{B. The Post-World War II Boom}

Virginia ranked fifth in national output of wood pulp in $1937,{ }^{144}$ and although the state's pulp-and-paper industries still lagged behind some Northern states, many Virginia companies invested their wartime profits in paper manufacturing to close that gap..$^{145}$ Efforts to build up the region's paper manufacturing accelerated when paper demand soared-and lumber demand slumped again-after World War II. In 1951, for example, the Camp Manufacturing Company invested $\$ 2.5$ million to build a new paper plant at its Franklin mill that drastically increased the company's production capacities. ${ }^{146}$ Only three years later, the company allocated another $\$ 34$ million to purchase new paper machines for those operations. ${ }^{147}$ Even companies from industries not traditionally tied to timber were investing in the newly profitable industry. These new market entrants included the

(discussing the plant opened by the Chesapeake Pulp \& Paper Company in West Point, east of Richmond).

143. Hitchcock, supra note 142 , at 489.

144. Sven A. Anderson, Trends in the Pulp and Paper Industry, 18 ECON. GEOGRAPHY 195, 199 (1942). Actual paper production lagged behind wood-pulp production because the early Virginia wood-pulp plants were located in Hampton Roads, where shipping lanes provided easy access to Northern markets. See Hitchcock, supra note 142, at 489 ("Convenience to both northern and southern markets and, through Hampton Roads, to world markets encourages the manufacture of any paper commodity whose production is not limited by remote sources of lowcost bulky raw materials."). Likewise, many older mills in the Northern states did not make their own pulp, relying instead on other sources like the ones in Virginia. See Anderson, supra, at 200 ("Many paper mills do not produce their own pulp, but purchase it from various sources. In normal times the mills of eastern United States rely very largely upon imported Canadian, Scandinavian, and Finnish pulp for their requirements.").

145. See Pikl, supra note 127, at 272 ("With more than two-thirds of the nation's postwar additions to pulping capacity taking place in the South, by 1958 the region was able to boast of producing 60 per cent of the country's woodpulp and more than 40 per cent of its paper and paperboard.").

146. Cf. Rouse, supra note 132, at 161 ("Success in kraft papermaking led Camp Manufacturing Company, Inc., in 1951 to build a $\$ 2,500,000$ plant at Franklin to produce white paper from pine. It was another step upward. Housewives preferred white rather than brown cartons for milk and frozen foods, and the new white paper technique opened up new markets.").

147. See id. at 7-8 ("Hugh Camp delayed moving his residence . . . to complete installation of the No. 4 paper machine the Camp board had initiated at his behest in 1954. The huge \$34million machine dwarfed the three installed earlier . . . In 1966, after Hugh had become [Union Camp's] chairman, the Franklin mill added its machine No. 5 at a cost of $\$ 37$ million.”). By 1955, observers were already referring to the lumber company as merely the operator of a "paper mill" without any mention of its continuing lumber operations. See, e.g., Camp v. Murray, 226 F.2d 931, 932 (4th Cir. 1955). 
Continental Can Company, ${ }^{148}$ which purchased a plant in 1947 and then invested between $\$ 22$ million and $\$ 25$ million to increase the plant's capacity four years later. ${ }^{149}$

These investments caused pulp-and-paper operations to expand quickly across the South, which by the mid-1950s was home to threefifths of the nation's paper manufacturing capacity. ${ }^{150}$ Paper manufacturers suddenly found their timber inventories understocked and sought to expand their woodland holdings quickly to meet growing manufacturing demands. The Camp Manufacturing Company, for example, expanded its local woodland holdings from approximately 106,000 acres in $1936^{151}$ to 240,000 acres twenty years later. ${ }^{152}$ Other companies, including many that brought new technologies and greater efficiency to paper production, similarly sought to acquire more timberlands. ${ }^{153}$

Demand for timber was such that state officials and manufacturers began fearing an imminent timber shortage in southeastern Virginia. ${ }^{154}$ Timber harvesting and pulp processing were

148. As its name suggests, the Continental Can Company was primarily a metal-container company. See United States v. Cont'l Can Co., 378 U.S. 441, 445 (1964) (noting that in 1955 the company was "the second largest company in the metal container field," but that it had also acquired numerous other packaging companies, including fourteen separate "producers of paper containers and paperboard").

149. Hercules Powder Co. v. Cont'l Can Co., 86 S.E.2d 128 (Va. 1955).

150. See Merle Prunty, Jr., Recent Expansions in the Southern Pulp-Paper Industries, 32 ECON. GEOGRAPHY 51, 51 (1956) ("In 1944, the South was responsible for about 44 per cent of domestic pulpwood output. By 1952, total southern production . . . accounted for 58 per cent of all United States pulpwood cut. [P]roduction [in 1953] increased to . . 61 per cent of domestic production."); see also supra note 145.

151. Camp Mfg. Co. v. Comm'r, 3 T.C. 467, 468 (1944). In addition to owned land, the company also had 15,000 acres of contractual timber rights. Id.

152. RousE, supra note 132 , at 5.

153. See id. ("[L]and and timber in the Southern pine belt were growing rapidly in value in the 1950 s . . . ."); id. at 12 ("[Franklin's] employment in lumber and paper manufacturing has steadily prospered. . . . Timber values have increased, and the purchase of raw materials of all sorts, especially timber and pulpwood, has expanded as more and more high-technology machines are brought on line.").

154. See Hercules Powder Co., 86 S.E.2d at 131 ("Mr. George W. Dean, State Forester of Virginia, testified that the pine situation was 'acute', and that on the basis of the latest survey of Virginia forests conducted in 1952 by the United States and Virginia Forest Services, the drain, or decrease in the Virginia pine, exceeded the growth of pine since 1940 by $16 \%$."); see also S.J. Res. 22, 1954 Gen. Assemb., Reg. Sess. (Va. 1954), reprinted in FOREST RESOURCES OF VIRGINIA: REPORT OF THE COMMISSION TO THE GOVERNOR AND THE GENERAL ASSEMBLY OF VIRGINIA 7, 7 (1955) (recognizing that "the volume of merchantable timber in Virginia ha[d] been shown by recent surveys to have declined at an alarming rate" and creating a commission to investigate the decline and develop recommendations for practices and regulatory measures that might alleviate the situation). 
proceeding at such a rate that mills were attracting new workers faster than the area's housing supply could keep pace. ${ }^{155}$ The rise in demand for timber led to a dramatic rise in timber prices, which naturally led to a corresponding escalation of land prices across the southern pine belt. ${ }^{156} \mathrm{By}$ then, the pulp-and-paper industry was already on its way to becoming the third-largest producer of wealth in the South. ${ }^{157}$ Thus, despite rising land and timber prices, the industry continued purchasing vast quantities of timber, investing in new timberlands, and even increasing processing capacity.

Figure 1. Rapid Increase in Market Price for Southern Pine ${ }^{158}$

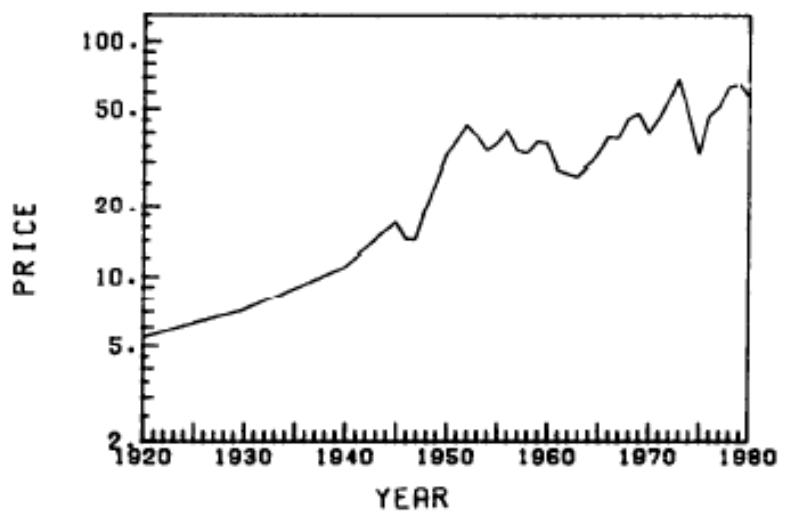

B. Southern pine

155. See Camp v. Murray, 226 F.2d 931, 932 (4th Cir. 1955) ("The post war increase of the [Camp Manufacturing Company] in 1947 led the company to bring many new employees to Franklin and a critical shortage of house sites arose because none were available in the town and the adjacent lands were owned by members of the Camp and other families who declined to sell.”). In 1948, under increasing pressure, Hugh G. Camp, a company vice president, was reluctantly persuaded to sell his own personal farmland to be used as residential land for town newcomers and Camp's new workers. Id. at 931-32.

156. See supra note 153. The market value of the Ferguson farm appears to have mirrored these trends. In 1938, a judicial sale priced the farm at \$3600. Deed, supra note 60, at 600, 600 . In 1943, Zehmer purchased it for \$11,000. See Lucy v. Zehmer, 84 S.E.2d 516, 518 (Va. 1954) ("[Zehmer] bought this farm more than ten years ago for $\$ 11,000$."); Record, supra note 20, at 56 (acknowledging that Ferguson had conveyed the deed to Zehmer in 1943). About three years later, Lucy-in his first attempt to purchase the farm-offered Zehmer \$20,000. See Lucy, 84 S.E.2d at 518 ("Seven or eight years ago [Lucy] had offered Zehmer \$20,000 for the farm which Zehmer had accepted, but the agreement was verbal and Zehmer backed out.”). In 1952, the allegedly agreed-upon price was $\$ 50,000$. Id . at 517 .

157. See Malsberger, supra note 139, at 639 ("The pulp and paper business in the South ... $\operatorname{rank}[\mathrm{ed}]$ as about the third largest wealth producer [in 1956].").

158. U.S. DeP'T OF Agric., Resource Bulletin No. FPL 11, Trends IN ECONOMIC SCARCITY OF U.S. TIMBER COMMODITIES 4 (1982), available at http://www.fpl.fs.fed.us/ documnts/fplrb/fplrb11.pdf (listing prices in 1967 dollars for one thousand board feet of timber). 
As these companies pursued standing timber across vast new tracts of land, they recognized the potential public outcry in communities encroached upon by the paper industry's expanding reach. ${ }^{159}$ For a variety of reasons, the industry ultimately followed a business model that relied on middlemen to obtain the timber resources necessary to sustain its tremendous growth-a strategy that would eventually bring Lucy and Zehmer face-to-face over drinks a few nights before Christmas in 1952.

\section{Southern Industry and Southern Law: The Rise of the Timber Broker}

Almost from the very beginning of the South's lumber and paper industries, the law played an important role in determining industrial profits and, subsequently, in shaping the business strategies of large mill operators.

As the lumber industry took hold at the beginning of the twentieth century, it confronted a serious logistical challenge that stymied its growth. The local pattern of landownership was highly decentralized, with most timberlands belonging to small family landholders, and thus posed considerable obstacles to mill operators' ability to access the region's forests. In 1908, the circuit court of Brunswick County described the problem: "the territory in southside Virginia is so divided into ownerships of small tracts, that it is

159. The feared outcry could be compared to the similar political agitation and revolts caused by the English enclosure movements between the thirteenth and nineteenth centuries. As Professor Allison Dunham suggests, early enclosure movements in England were less controversial, and less forceful, than later efforts:

[G]iven the apparent economic desirability of consolidation of agricultural operations in England, the destruction of the system of villages and fields and the voluntary allocation of the rural land of England to consolidated argricultural [sic] uses resulted from the normal operation of the market mechanism. Consents were obtained by purchase and the self-interest of the farmers.

Allison Dunham, From Rural Enclosure to Re-Enclosure of Urban Land, 35 N.Y.U. L. REV. 1238, 1241-42 (1960). By the late eighteenth century, however, the amount of land being enclosed led some local farmers to resist enclosure efforts even when market forces offered strong incentives for farmers to agree to them. As Dunham explains,

Rural conservatism, as some of the English literature described it, finally produced a situation where not all of those who had rights to pasture in the common waste land would consent to its enclosure, or at least consent at prices which the majority, even given the economic advantage of enclosure, could afford to pay.

Id. at 1242 . 
necessary to purchase from hundreds of farmers in order to justify the erection of a modern saw-mill plant. ${ }^{\prime 160}$

The region's large mill operators handled the problem of decentralized land ownership by negotiating a web of standard contracts securing the right to harvest and transport standing timber from hundreds of small property owners. ${ }^{161}$ Although individual contracts often involved small quantities of timber, litigation over even the smallest timber deeds consumed a considerable amount of time for large mill operators. ${ }^{162}$ The widespread use of standard timber contracts also often raised large operators' stakes in even the smallest disputes because an unfavorable precedent affecting the interpretation of key contract provisions could provide ammunition to other farmers seeking similar redress-multiplying the company's potential losses well beyond the amount of timber on any single farm. ${ }^{163}$

Early on, Virginia's highest court appeared unsympathetic to these concerns. In 1910, for example, the Virginia Supreme Court chided the circuit court in Brunswick for taking "judicial notice of the operations of a large manufacturing concern" deference to a large mill operator because of its importance to the local economy. ${ }^{165}$ Perhaps because of these challenges, some mill operators soon began purchasing local timberlands outright rather

160. Camp Mfg. Co. v. Young, 14 Va. L. Reg. 89, 99 (Va. Cir. Ct. 1908), rev'd in part, 66 S.E. 843 (Va. 1910).

161. See generally id. (noting the importance of contracts with individual farmers to the paper business).

162. See, e.g., RousE, supra note 132, at 48 ("Like other lumber-cutters, Camp was frequently in court in cases contesting the boundaries of its timberlands. Such litigation usually grew out of ill-defined property lines on recorded land plats, some dating back to colonial years. Often such landmarks as large trees cited by early surveyors had disappeared, creating confusion. Especially troublesome was legal title to remote woodlands, . . . which had rarely been timbered.").

163. Young, 14 Va. L. Reg. at 90 (explaining that two consolidated test cases were particularly important because the questions raised about the standard timber deeds used by the Camp Manufacturing Company involved "principles which can arise in more than one hundred other cases, and which will settle the title to standing timber valued at perhaps more than one million dollars").

164. Id.

165. See Young v. Camp Mfg. Co., 66 S.E. 843, 847-48 (Va. 1910) ("[W]e cannot think that the rights of the appellants should be controlled by the magnitude of the business in which the Camp Manufacturing Company is engaged.... [T] he rights of appellants are not to be measured by the convenience or inconvenience, the ability or the inability, of the Camp Manufacturing Company, caused by and resulting from the magnitude and extent of its business, and its numerous other contracts to which these appellants are strangers.”). 
than purchasing the standing timber on these properties. ${ }^{166}$ But even land purchases brought litigation risks. ${ }^{167}$

Anticipating the hazards from litigation, and hoping to avoid further cumbersome relations with local landowners, mill operators such as the Camp Manufacturing Company began to rely increasingly on local family-owned lumber companies to supply their timber needs. ${ }^{168}$ These lumbermen worked as middlemen to help the mill operators acquire timber rights in peripheral regions without alarming local residents. ${ }^{169}$ When legal disputes arose, these local middlemen also presented the courts with more sympathetic parties. ${ }^{170}$ Relying on local lumbermen had the additional benefit of keeping land acquisitions quiet, which proved to be useful when land was undervalued. The use of middlemen transformed the industry's structure and had meaningful consequences for the region's smaller lumbermen, including the Lucy brothers.

166. See generally CAMP MFG. CO., SiXTY YeARs OF Progress (1948) (detailing the company's boasts that by the late 1940s, Camp's lumber and paper operations relied almost exclusively on timber cut from repeated harvests on company-owned lands).

167. See Camp Mfg. Co. v. Green, 106 S.E. 394, 400 (Va. 1921) (holding that a suit against Camp Manufacturing Company was only prevented by the lapse of time between the injury and the action); Seward v. Camp Mfg. Co., 71 S.E. 614, 617 (Va. 1911) (concluding that the Camp Manufacturing Company had a right to some, but not all, of the land it had purchased).

168. See, e.g., Mitch Zemel, Va. Grows Growth Industry, RICH. TIMES-DisPATCH, Sept. 10, 1990, available at NewsBank, Rec. No. 9002100828 (referencing the "many small logging companies, which stay in business by getting contracts to cut trees from the . . Union Camps of the industry").

169. Concerns about industrial landgrabs alarming local residents were far from hypothetical. Rural communities were particularly sensitive to industry efforts to secure wide swaths of farming territories. See Prunty, supra note 150, at 52-53 ("Despite efforts to avoid undue local concentrations of ownership, some have occurred and criticism has resulted.").

170. This strategy was apparently successful in shielding Camp Manufacturing Company from litigation. In spite of the company's several legal battles in the early 1900s, we could not find a single Virginia Supreme Court case involving timber or land purchases to which the Camp Manufacturing Company or its successor company, the Union-Camp Bag Company, was a party from 1936 to 1956 . An exhaustive search of cases in state and federal courts in the 1940s and 1950s only turns up one case involving the Camp Manufacturing Company and disputed rights to timber, heard before a federal district court in 1942 in South Carolina. See Nelson v. Camp Mfg. Co., 44 F. Supp. 554, 557 (E.D.S.C. 1942) (considering a trespass action in which Camp Manufacturing Company was the defendant). This is in spite of the company's substantial growth during that period; the company more than doubled its land ownership and timber intake. See Camp Mfg. Co. v. Comm'r, 3 T.C. 467, 468 (1944) ("In 1936 petitioner owned in fee approximately 106,000 acres of timber lands and held timber rights in 15,000 additional acres."); see also supra note 152 and accompanying text. Indeed, to our knowledge, none of the major industrial leaders of the Southern pulp-and-paper industry litigated cases with farmers over timber or land before the Virginia Supreme Court in those years. 
As the pulp-and-paper industry began to displace the lumber industry in the late 1940s, it also inherited the lumber industry's problems. First and foremost among those problems was the region's divided land ownership. In the words of a contemporary source,

The small landowner is the key to the future of the pulp and paper industry in the South. The industry does not own enough land to support itself, and for the future it appears as though industry must expect the small landowner to supply 50 percent of its total requirements. This small landowner looms very large and important whenever southern forestry is deliberated. ${ }^{171}$

By the mid-1950s, pulp-and-paper manufacturers purchased 75 percent of their timber requirements from local landowners. ${ }^{172}$ Industrial leaders grew increasingly aggravated, however, by the low productivity of forests controlled by small landowners as compared to lands owned by industrial interests, ${ }^{173}$ so pulp-and-paper companies across the South preferred instead to acquire more direct control over Southern timber and timberlands. ${ }^{174}$

A second familiar problem was the farmers' "sensitiv[ity] to the manner in which markets for wood-stuffs conduct themselves." Thus, corporate leaders feared that sudden acquisitions of large tracts of land, in addition to driving up purchase prices, would anger the same local farmers upon whom they relied for a majority of their timber resources. ${ }^{176}$ Mill owners of the 1950s, like their predecessors forty years earlier, navigated these straits by trying to mask their acquisitions of additional timberlands, both by looking to more

171. Malsberger, supra note 139, at 642.

172. See id. at 641 (noting, in a source dated 1956, that the industry bought 75 percent of its raw materials on the open market). As late as 1990, these private-property owners were still providing more than 70 percent of the timber required by Virginia's timber-consuming industries. Zemel, supra note 168.

173. See Malsberger, supra note 139, at 641 (comparing productivity rates for industrial forests, rated as high as 96 percent, to the rates for individual tracts of land, rated as low as 40 percent).

174. See Prunty, supra note 150, at 52 ("Customarily these mills have obtained ownership (or control through long-term leases) of sufficient nearby woodland to insure annual pulpwood production equivalent to approximately one-third of mill requirements."). These attempts were ultimately successful. See Zemel, supra note 168 (noting that by 1990, "[m]any larger companies rel[ied] heavily on their own timberland").

175. Prunty, supra note 150 , at 53 .

176. This was more than a hypothetical fear. A local commentator observed that "[d]espite efforts to avoid undue local concentrations of ownership, some have occurred and criticism has resulted." Id. at 52-53. 
remote sources of timber where their activities might arouse less concern and by employing middlemen to conceal the true purposes of land or timber transactions. A report issued by the state's commission on forest resources in 1955, for example, describes the rise of "pulpwood contractors" who did "the great majority of cutting [of timber] in Virginia ... predominantly on small ownerships of farmers and non-resident investors." described as "timber broker[s]" - formed networks of individual lumbermen who acquired timber rights and then harvested timber for the state's large and rapidly expanding pulping operations. As such, several small family-owned businesses whose core businesses previously had been harvesting timber and producing lumber products transformed themselves from independent manufacturers to middlemen who profited by searching for and securing raw timber materials for Virginia's burgeoning pulpwood operations. ${ }^{179}$

This strategy, when coupled with rapidly rising timber and timberland prices, had the unintended result of inspiring an unrestrained landgrab. The combination of rising land values and the proliferation of aggressive middlemen led to an explosion of quickly executed and wildly unseemly property sales. Many sales involved shady practices and little disclosure, often causing family sellers to agree to prices far below prevailing market rates. A study commissioned by the Virginia legislature found the problem to be sufficiently problematic to conclude that sawmill operators "ha[d] taken full advantage of the landowner's ignorance of timber matters." ${ }^{180}$ Several of these disputes over rapid land sales resulted in litigation and left behind a colorful legal history.

\section{The Timber Broker and the Courtroom}

As early as the late 1920s, and especially in the booming 1940s and 1950s, the Virginia Supreme Court regularly heard cases between local landowners, individual lumbermen, and local lumber companies. ${ }^{181}$ These cases often pitted neighbors, families, and even

177. FOREST RESOURCES OF VIRGINIA, supra note 154, at 28.

178. Owen v. Wade, 37 S.E.2d 759, 760 (Va. 1946).

179. See Zemel, supra note 168 (describing how small family businesses survived by supplying large pulp-and-paper producers with timber).

180. FOREST RESOURCES OF VIRGINIA, supra note 154, at 50.

181. Between 1926 and 1957, the Virginia Supreme Court decided at least thirty-seven cases-in addition to Lucy v. Zehmer - that involved disputes over timber or timberlands. See, e.g., Barnes v. Moore, 98 S.E.2d 683, 687 (Va. 1957) (affirming a judgment of willful trespass 
former business partners against each other over the control of the region's trees and timberlands. Even the early history of the Ferguson farm contributed to this line of land disputes. After M.L. Ferguson, an elderly widow, bequeathed the property in nine equal shares to members of her family, one of those family members, Dr. J.H. Ferguson, offered to buy the remaining interests from the others. ${ }^{182}$ Three ultimately agreed to sell, and Dr. Ferguson sued the remaining five for their shares. ${ }^{183}$ Represented by William Earle White, a prominent local attorney, Dr. Ferguson successfully persuaded the court to order a judicial sale of the property in which he, in the "best interest of all parties in interest," would pay $\$ 2000$ to be divided between the five holdouts. ${ }^{184}$ Five years later, Dr. Ferguson sold the

against a neighbor who cut the plaintiff's timber); Raney v. Barnes Lumber Corp., 81 S.E.2d 578, 586-87 (Va. 1954) (finding no contract between a plaintiff lumber company and the heirs to an owner of timberlands); Goin v. Absher, 53 S.E.2d 50, 53 (Va. 1949) (overturning a trial court judgment that a lumberman had properly exercised an option to extend a timber deed); Kiser v. W.M. Ritter Lumber Co., 18 S.E.2d 319, 320 (Va. 1942) (reviewing an action by heirs to recover damages from timber removal after a company entered a contract with an incapacitated landowner); Brunswick Land Corp. v. Perkinson, 151 S.E. 138, 141 (Va. 1930) (affirming trespass by a neighbor who removed trees from the plaintiff's property); Morriss v. White, 131 S.E. 835, 840 (Va. 1926) (finding no cause of action for reimbursement of the value of timber that had been removed before the property had been conveyed to the plaintiff). The North Carolina Supreme Court heard similar cases. In Roberson v. Williams, 83 S.E.2d 811 (N.C. 1954), which occurred just across Virginia's southern border, a lumberman-after repeatedly trying to buy rights to timber on a widow's farm, $i d$. at 811 -finally induced the widow to sell those rights with assurances that $\$ 10,000$ was a "good price," $i d$. at $814-15$. Forty-nine days later, the lumberman sold the same rights to a lumber company for nearly double that price. $I d$. at 811-12. When the widow discovered the difference in prices, she filed suit for actionable fraud. Id. The North Carolina Supreme Court ultimately held that when a widow had been told that she was being offered a "good price," and those words had induced her to part with her property for half its value, the widow was entitled to present her case to a jury. Id. at 811,815 .

182. Ferguson v. Ferguson (Va. Cir. Ct. Dinwiddie County 1938) (on file with the Duke Law Journal). This document is available on page 501 of the Dinwiddie County Chancery Order Book No. 4.

183. Id.

184. Id. In resolving the suit, William Earle White was appointed special commissioner to arrange the sale, which was accomplished by deed on December 14, 1938; pursuant to the sale, Dr. Ferguson officially took control over the farm for the sum of $\$ 2000$. See Deed, supra note 156, at 600-01 ("This deed, made this 14th day of December, in the year 1938, by and between William Earle White, Special Commissioner, party of the first part, and J. H. Ferguson, party of the second part. ... Whereas, the court by a decree . . . accepted and confirmed the offer of J. H. Ferguson for the purchase of the hereinafter described real estate for the sum of two thousand dollars ... ."). It should be noted that there was reportedly a "poor market for timber" in 1938 - the year of the judicial sale. See Straley v. Fisher, 10 S.E.2d at 551, 552-54 (Va. 1940) (explaining why a lumberman had not removed all the timber between February and December 1938 , as he had been authorized to do under a contract). 
farm to Zehmer for $\$ 11,000{ }^{185}$

Several other land disputes also resulted in lively litigation, and one person who regularly was at the fore of that litigation was Harrison. After becoming a state senator, but before his election as Virginia's attorney general, Harrison frequently represented parties in disputes over southern Virginia land. Harrison, for instance, was the lead defense attorney in Jackson $v$. Seymour ${ }^{186}$ a case that has appeared in textbooks for at least as long as Lucy v. Zehmer ${ }^{187}$ and that has been cited to demonstrate principles related to unconscionability, ${ }^{188}$ fiduciary duties, ${ }^{189}$ and constructive fraud. ${ }^{190}$ Jackson involved a widow who, after having sold her family land to her brother, discovered that her brother had profited handsomely from harvesting timber on the land. ${ }^{191}$ After the brother refused to share the profits with his sister-or even to disclose to her what those profits had been, though it was later revealed that they approached ten times the land's sale price ${ }^{192}$ - that widow, Lucy S. Jackson, retained an attorney to take her brother to court for fraud. ${ }^{193}$ After Harrison successfully defended the contract at trial, Jackson appealed to the Virginia Supreme Court, which-though agreeing with Harrison that Jackson had failed to prove actual fraud-took pity on the widow and ordered the contract rescinded and damages paid to

185. Deed, supra note 50, at 167; Record, supra note 20, at 34 (recording testimony from Zehmer about how much he had paid when he originally bought the farm).

186. Jackson v. Seymour, 71 S.E.2d 181 (Va. 1952).

187. See PATTERSON ET AL., supra note 7, at 306 (discussing Jackson v. Seymour in a casebook dated 1957).

188. See, e.g., Note, Unconscionable Business Contracts: A Doctrine Gone Awry, 70 YALE L.J. 453, 453 \& n.3 (1961) (citing Jackson v. Seymour as an example of "courts hav[ing] protected widows and simpletons from the machinations of sharp traders by finding that gross inadequacy of consideration has made a contract 'unconscionable' and therefore unenforceable").

189. See, e.g., Todd D. Rakoff, Contracts of Adhesion: An Essay in Reconstruction, 96 HARV. L. REV. 1173, 1249 \& n.241 (1983) (mentioning Jackson v. Seymour as an example of an opinion that straddles the line between "treat[ing] a case as an arm's-length transaction subject to contract law" and "treat[ing] it as a relationship calling for the application of fiduciary principles").

190. See, e.g., Ingrid Michelsen Hillinger, The Merchant of Section 2-314: Who Needs Him?, 34 HASTINGS L.J. 747, 748 n.8 (1983) (using Jackson v. Seymour to support the proposition that "[t]he doctrine of constructive fraud requires a special relationship between the parties").

191. Jackson, 71 S.E.2d at 182-84.

192. See id. at 183 (noting that Jackson received $\$ 275$ for the land, that Seymour cut 148,055 feet of timber from his lands at a stumpage value of about twenty dollars per 1000 feet, and that a majority of the timber came from the land he had purchased from Jackson).

193. Id. at 184 
the plaintiff under a new cause of action known as constructive fraud. ${ }^{194}$

Several years later, Harrison was also the lead plaintiff's attorney in Barnes v. Moore, ${ }^{195}$ a case that arose out of negotiations over a tract of property between two lumbermen, Barnes and Cabiness, and a man named Love. ${ }^{196}$ Barnes, reportedly a "man of honesty and integrity,"197 was trolling Victoria County for timberlands with Cabiness when the two "found Love near his home."198 Eager to purchase Love's land, Cabiness "obtained a bottle of whiskey for Love, and after the latter had taken a drink, they began negotiations." ${ }^{" 199}$ Eventually, they reached a deal, and the lumbermen began cutting and removing the timber. ${ }^{200}$

In a predictable plot twist, Barnes and Cabiness discovered that Love did not actually own the property in question, ${ }^{201}$ and the real landowners retained Harrison to sue the lumbermen for trespass for taking timber from their lands. ${ }^{202}$ Harrison argued, and the Virginia Supreme Court agreed, that the lumbermen had acted with gross negligence. ${ }^{203}$ Noting that "Barnes and Love were kinsmen," the court chided Barnes for exploiting a member of his own community and for doing business upon such shaky grounds. ${ }^{204}$ In the end, the court

194. Id. at $184-86$.

195. Barnes v. Moore, 98 S.E.2d 683 (Va. 1957).

196. Id. at 684-85.

197. Id. at 686 .

198. Id. at 685 . The court was presumably referring to the incorporated town of Victoria in Lunenburg County, Virginia, which is a one-hour drive from McKenney along State Highway 40. That route would take a visitor directly through the Ferguson farm because Highway 40 runs directly across the property. Record, supra note 20, at 17.

199. Id.

200. Id.

201. Id.

202. Id. at $683-84$.

203. Id. at 687 . The justification for finding that the lumbermen had been grossly negligent in swiftly executing such a land sale comes from the court's description of Love:

He was eighty-two years of age, blind in one eye, with defective vision in the other, and feeble both physically and mentally. He had given up his business affairs about ten years ago, and such matters were attended to by his wife and other members of his family. He was kindly disposed, addicted to drinking alcoholic beverages whenever available, and easily influenced by other people, especially when drinking.... These conditions surrounding Love were generally known in his community.

Id. at $685-86$.

204. Id. at $686-87$. 
ordered the lumbermen to pay damages to the real landowners ${ }^{205}$ and Love suffered no consequences from enjoying his free drink.

In between these two representations, Harrison represented the Lucy brothers in Lucy v. Zehmer. Together, the three cases paint a colorful picture of disputed land sales between eager and, at times, unscrupulous purchasers and landowners unaware of their land's unrealized value. They further illustrate how an economic shock to asset prices can insert a wedge - and litigation - into intimate social and family relations. The cases also suggest that Zehmer's negotiations with Lucy took place within a distinct economic context. The region's large industrial concerns created valuable economic opportunities for land purchasers, and although many farmers were unaware of the land's worth, many others understood that the timber they owned was rising in value. As the region's mills used local intermediaries to acquire timber resources, aggressive middlemen trolling for land sales proliferated in the county's farmlands and often found themselves defending their business practices in court. As we describe in the next Part, the Lucy brothers had a lucrative run working as such middlemen, and their journey to the Virginia Supreme Court began with a plan to obtain what they believed was the crown jewel of Dinwiddie's vast timber reserves: the aged timberlands located on the Ferguson farm.

\section{Not Just A TALE OF TWO LUMBERMEN}

In part, Lucy v. Zehmer is a tale of two brothers in southern Virginia who, like the Camps-and even the Zehmers-before them, made a fortune by buying undervalued forested properties in remote areas and selling the timber from those properties for more money than they had paid for the land as a whole. The Lucys' rise to prosperity, however, was a distinct reflection of the region's industrialization, as the brothers capitalized on the regional mills' need for timber brokers. The brothers thus contributed to the transformation of southern Virginia's economy from one that relied on farming to one that rested on harvesting natural resources for industrial use.

205. Id. at 684,687 . These cases also demonstrate Harrison's versatility as an attorney. In Barnes v. Moore, Harrison represented landowners and convinced the Virginia Supreme Court to rule against the allegedly irresponsible or unethical practices of timber harvesters. In Lucy $v$. Zehmer, by contrast, Harrison convinced the same court that a contract should be upheld on behalf of a timber harvester against a purportedly irresponsible landowner. 


\section{A. The Secret to the Lucys' Success}

Property records reveal that the Lucy brothers signed dozens of land and timber deeds between the 1930s and the 1960s. ${ }^{206}$ Though generally involving properties smaller than the 471.6-acre Ferguson farm, these deeds reflect a pattern of business activity in Dinwiddie and Brunswick Counties: The Lucy brothers would purchase farmland and then harvest the timber for sale to the Camp Manufacturing Company or another large paper mill. Sometimes the Lucys would resell the land after removing the timber, but often the immediate returns from harvesting would enable the Lucys to keep much of the land. ${ }^{207}$

Engaging in such activity required a keen eye for "cruising," the process of strolling through a property to determine the value of its timber, and the descendants of John and Welford Lucy described Welford as a true master of the trade. ${ }^{208}$ Cruising usually involved taking careful measurements of a land's timber and making calculations based on market prices, but Lucy family lore describes Welford as someone who could stroll around a property and intuitively make an accurate assessment of its value. ${ }^{209}$ In fact, Welford admitted in a deposition that he had driven around Zehmer's property several times in the years prior to making his offer of $\$ 50,000$ in December 1952, including one trip three weeks before the disputed sale. ${ }^{210}$ Those trips suggest that Welford's eventual offer was based on a reasoned analysis of the value of the property's timber rather than on an impulsive wager.

206. In Dinwiddie County alone, Welford and John C. Lucy are listed as grantees on at least thirty-four separate land or timber deeds and as grantors on fifty-one such deeds. Indices of these deeds are on file with the Duke Law Journal.

207. John C. Lucy's descendants recalled that he, especially, saw value in accumulating as much land as possible, instructing his sons, "Buy land if you can, because it is the one commodity that God is no longer making." Interview with John C. Lucy Jr., John C. Lucy III, and James Lucy, supra note 113. By adhering to that philosophy, John C. Lucy was able to leave thousands of acres of rural land to his sons when he passed away. Id.

208. Interview with Emory Lucy, supra note 118; Interview with John C. Lucy Jr., John C. Lucy III, and James Lucy, supra note 113; Interview with John C. Lucy III and John C. Lucy IV (Feb. 16, 2007); Interview with Meade Lucy, supra note 119; see also Timber Cruising, U.S. FOREST SERV., http://www.fs.fed.us/fmsc/measure/cruising/index.shtml (last updated Aug. 30, 2011) ("Cruising is the process of measuring forest stands to determine stand characteristics, such as average tree sizes, volume, and quality. The primary purpose of cruising is to obtain a volume estimation to appraise and prepare timber sales.").

209. Interview with John C. Lucy Jr., John C. Lucy III, and James Lucy, supra note 113; Interview with Meade Lucy, supra note 119.

210. Record, supra note 20, at 61-62. 
Lumbermen like the Lucys profited not only from intuitive cruising but also from fostering continuing relationships with the region's mills. When the Camp Manufacturing Company needed to expand its reach farther into Brunswick and Dinwiddie Counties, for example, it turned to John C. Lucy and other lumbermen to purchase new land and then turn over the timber. ${ }^{211}$ John first entered the lumber business on his own, scraping together enough money for a small sawmill. ${ }^{212}$ Before long, his descendants recalled, the Camp Manufacturing Company had reached out to him to be their "wood agent" in Brunswick County, offering him set prices for all timber shipped. ${ }^{213}$ John's frequent business with Camp led him to build a lumberyard in Brunswick County from which he sent regular shipments of timber to the company by train. ${ }^{214}$ It was a good business John C. Lucy Jr. recalls; it was "just like picking money off trees." 215

\section{B. Answering the \$50,000 Question}

Both the region's economic history and the parties' personal histories clarify the events that surrounded Lucy's meeting with Zehmer shortly before Christmas in 1952 . They also help illuminate the court's determination that $\$ 50,000$ was a fair price for the Ferguson farm. Timber prices, and thus timberland prices, were skyrocketing, and neither historic prices nor the tax assessment values relied upon by the court accurately reflected appropriate timberland values. In fact, the Ferguson farm's history leading up to 1952 had contributed to its growing value.

Owned by a widow, then by an absentee landlord, and then by nonlumberman Zehmer, the farm's forests had been allowed to grow

211. Interview with Emory Lucy, supra note 118; Interview with John C. Lucy Jr., John C. Lucy III, and James Lucy, supra note 113.

212. Interview with Emory Lucy, supra note 118; Interview with John C. Lucy Jr., John C. Lucy III, and James Lucy, supra note 113.

213. Interview with John C. Lucy Jr., John C. Lucy III, and James Lucy, supra note 113.

214. Interview with Emory Lucy, supra note 118. John C. Lucy Jr. believed that the arrangement had begun with an oral contract under which Camp agreed to pay John C. Lucy Sr., one dollar for every cord of pulp wood shipped each week. Interview with John C. Lucy Jr., John C. Lucy III, and James Lucy, supra note 113. He estimated that his father had been one of Camp's largest agents, sending between 50,000 and 60,000 cords of timber a year. Id. The Virginia Department of Forestry defines a cord as the amount of wood contained in a space of 128 cubic feet when the pieces are stacked compactly in touching, parallel rows. Firewood for Home Heating, VA. DEP'T OF FORESTRY, http://www.dof.virginia.gov/mgt/firewood.htm (last visited Mar. 19, 2012). A "standard cord" measures four feet high, four feet wide, and eight feet long. Id.

215. Interview with John C. Lucy Jr., John C. Lucy III, and James Lucy, supra note 113. 
unharvested for decades. As a result, the farm "was an excellent tract of timber," ${ }^{216}$ a fact supported by several depositions in the appellate record. ${ }^{217}$ S.E. Winn Jr., a local sawmill operator, testified that he had made several past attempts to buy the farm, including an attempt to buy its timber in December 1952, shortly before Welford made his offer. ${ }^{218}$ John Will Rives, a local game warden, reported having had "a number of conversations" with Zehmer about "the saw timber" on the property. ${ }^{219}$ Zehmer himself testified that he had turned down twenty-five similar offers for the farm. ${ }^{220}$

Welford and his brother, who were operating lucrative businesses as timber brokers for southern Virginia's large pulp-andpaper interests, were ideally positioned to capitalize on the land's value. They had a history of harvesting timber for paper companies and of buying and selling timberlands for healthy profits, and their business success was sufficient to give them access to credit lines that were apparently beyond the imagination of Zehmer. ${ }^{221}$ They might reasonably have been able to extract the most value from the farm, and thus might have been able to offer a price sufficiently higher than any competing broker-a price that would have surprised Zehmer.

216. Interview with John C. Lucy Jr., John C. Lucy III, and James Lucy, supra note 113. In addition, one neighbor reports that the property was not particularly valuable as a farm, but that it was valuable instead as a relatively untouched forest. Interview with Floyd M. Harrison Jr., supra note 110 .

217. Record, supra note 20 , at $82-85$.

218. Id. at $82-83$.

219. Id. at $84-85$.

220. Lucy v. Zehmer, 84 S.E.2d. 516, 518 (Va. 1954). Zehmer testified that he had told Lucy that he was turning down the offers because he "want[ed his] son to have [the farm]." Id. at 520 (quoting Zehmer). Zehmer's insistence on leaving the lands untouched for his son could be seen as a Zehmer family tradition, but more likely, Zehmer was retaining an asset growing in value for when he or his son needed capital. Other family members also reportedly let their timberlands sit except when funds were needed-for example, to pay the college tuitions of their children. ZEHMER, supra note 91, § 8, at 11.

221. One neighbor, Floyd M. Harrison Jr., reports that Zehmer had thought Lucy was bluffing about his ability to get $\$ 50,000$, but that Zehmer had known that he had been cheated as soon as Lucy came forward with the money. Interview with Floyd M. Harrison Jr., supra note 110. Another neighbor, who was at the other end of the counter at Ye Olde Virginnie when Lucy met Zehmer in 1952, believes that Zehmer had known that Welford Lucy did not have the money to back up his offer, but that Zehmer had forgotten about Welford's brother, John Cleveland. Telephone Interview with Roper Howard (Oct. 15, 2009). This explanation sits well with John Cleveland's descendants. See, e.g., Email from John C. Lucy III to author, supra note 116 (containing comments from Emory Lucy explaining that he "ha[d] always been under the impression that [John Cleveland had] guaranteed a portion of the funds because Uncle Welford could not come up with it on his own"). 
In addition, Lucy's exceptional talent for appraising timber value without conducting extensive measurements allowed him uniquely to estimate the farm's potential value. The record suggests that the Zehmers, by contrast, thought little of the land's natural resourcesor at least that they were much less attuned to the land's timber value than the nearby community of lumbermen. Ida and Hardy Zehmer, for example, both testified that the farm had no equipment or value except for the presence of a farmhouse and two head of cattle; they said nothing to suggest that the property contained valuable natural resources. ${ }^{222}$

Viewing the conversation between Zehmer and Lucy through this lens, one can understand why Zehmer might have thought that $\$ 50,000$ was an attractive price at first but changed his mind after realizing that it was so agreeable to Lucy. Zehmer likely became aware of his land's potential value only after Lucy walked out of Zehmer's restaurant excitedly waving the restaurant receipt-cumcontract. Lucy's zeal in enforcing the contract and Zehmer's strong resistance to selling are in tension with Justice Buchanan's proclamation that $\$ 50,000$ was, if not a windfall for Zehmer, a fair price for the land. A careful examination of Dinwiddie property records provides reason to question the accuracy of Justice Buchanan's valuation.

Subsequent events reveal the true value of the Ferguson farm. On December 17, 1954, Hardy and Ida Zehmer finally conveyed the Ferguson farm to the Lucys for the bargained-for price of $\$ 50,000{ }^{223}$ On January 5, 1955, less than a month after the final sale, the Lucy brothers executed a timber deed granting the right to all the merchantable timber on the property to the Lumber Distribution

222. A review of Ida Zehmer's deposition testimony, for example, reveals a telling exchange in which Harrison pushed Ida to describe objects of value on the property:

Q. What else did the word, "complete", include other than the land and buildings thereon?

A. I know of nothing else except the cows.

Q. There was no farming equipment on the property at the time?

A. Not that I know of.

Q. The property consisted of farm and buildings thereon? And two heads of cattle?

A. That is right.

Record, supra note 20, at 24. Harrison proceeded to ask Hardy Zehmer similar questions, and he received similar answers. See id. at 41 (recording an exchange in which Harrison asked whether "there [was] anything else [on the property] except a couple cows" and Zehmer replied, "No, sir").

223. Deed, supra note 25, at 365 . 
Company of Petersburg, Virginia. ${ }^{224}$ To execute this purchase, the Lumber Distribution Company borrowed $\$ 85,000$, suggesting that at least that much - and perhaps more-was paid to the Lucy brothers. ${ }^{225}$

By April 1956, the Lumber Distribution Company had removed all the merchantable timber from the formerly forested portions of the property and had filed a deed of release, freeing the Lucy brothers from their obligations under the contract and enabling them to otherwise dispose of the property. ${ }^{226}$ Immediately thereafter, Welford Lucy sold the formerly wooded portion of the property, which amounted to 367.7 of the original 471.6 acres, to the Continental Timber Lands Corporation, ${ }^{227}$ an affiliate of the Continental Can Company. ${ }^{228}$ Because the Continental Timber Lands Corporation evidently had no need to secure financing for the transaction, there is no public record of what Welford received in his truncated sale of the property. ${ }^{229}$

Following this sale, Welford leased the remaining 103.9 acres of the Ferguson farm - the portion suitable for farming-to W. Franklin Townsend, enabling Townsend to reside on the property as a tenant farmer and granting him an option to buy the property for $\$ 12,000$ as early as $1961 .^{230}$ On May 14, 1962, after Townsend had informed Lucy

224. Timber Deed (1955), in 91 DinwidDIE CounTy DeEd BooK 40, 40-42. Although this deed was officially notarized on January 5, 1955, it may have been first drawn up even earlier. For example, the agreement specifically grants the Lumber Distribution Company a period of three years from December 21, 1954, to cut and remove the timber on the property. Id. Presumably, this date was chosen for a reason. Id. at 41. Because the Lucy brothers only received a deed for the property from the Zehmers on December 17, 1954, Deed, supra note 25, at 365-a Friday - the brothers apparently had papers drafted to sell the property within two business days of having received the deed.

225. This figure is the amount recorded in the trust deed filed by the Lumber Distribution Company, which states the amount that the company had borrowed from the Petersburg Savings and American Trust Company to finance the sale. Deed of Trust (1955), in 91 DiNWIDDIE COUNTY DEED BOOK 44, 45. Ironically, one of Hardy Zehmer's attorneysWilliam Earle White-served as a trustee for the Petersburg bank in the transaction, id. at 46, and would accordingly have been able to see how much the timber on his client's farm was worth shortly after his loss before the Virginia Supreme Court, see Lucy v. Zehmer, 84 S.E.2d 516, 516, 522-23 (Va. 1954) (deciding against Zehmer on November 22, 1952).

226. Deed of Release (1956), in 95 DinwIDDIE COUNTY DEED BOOK 71, 71-72.

227. Deed \& Plat (1956), in 95 DinwIDDIE COUNTY DEED BOOK 72, 72-74.

228. Merger (1958), in 103 DinwIDDIE COUNTY DEED BOOK 402, 402.

229. Had the Continental Timber Lands Corporation borrowed finances to purchase the tract, a bank would have filed a trust deed on the property, which would have provided a better estimate of what Lucy received from the transaction. Despite an exhaustive search of local records related to the parties and the property, no such deed has been found.

230. Complaint at 1-2, Townsend v. Lucy, No. 611A (Va. Cir. Ct. Dinwiddie County 1962). 
that he intended to exercise this option and had arranged for the payment of the $\$ 12,000$, Lucy — not one to shy away from a fight or an opportunity-refused to deliver title to the property. ${ }^{231}$ Townsend and his wife filed a complaint to compel performance, again in Judge Jefferson's court, and later settled with Lucy for a revised price of $\$ 15,000 .^{232}$

Based on this evidence, we can begin to piece together the profits the Lucy brothers made from their purchase and truncated sale of the Ferguson farm. Assuming that the Lucy brothers sold the farm's timber for $\$ 85,000$ - the price that the Lumber Distribution Company borrowed from the Petersburg Savings and American Trust Bank $^{233}$ - and that the 367.7 acres of land sold to Continental were sold at the same per-acre price as the price originally agreed to by Welford and Townsend- $\$ 12,000$ for 103.9 acres $^{234}$-we estimate that by 1962 the Lucy brothers had earned at least $\$ 142,000$ from their $\$ 50,000$ investment less than a decade earlier. ${ }^{235}$

This is not a scientific calculation. It assumes for convenience that the previously wooded 367.7 acres were sold at the same price as the 103.9 acres that were used for farming and that contained the dwellings and farm equipment. Our calculation also does not include the income from leasing the farm to Townsend before the sale in 1962. Nonetheless, it is our best approximation based on the available evidence. If anything, reports from the Lucy descendants suggest that our estimate might be too conservative. John C. Lucy III, for example, recalled being told that John and Welford had earned at least four times what they had paid for the farm in $1954 .^{236}$ Taken

231. Id. at 3 .

232. Deed of Trust (1962), 114 DinwidDIE CounTy DEED BoOK 302, 302-04.

233. Because the timber was used as collateral for the loan, the loan likely would not have exceeded the value of the collateral.

234. At that agreed upon price- $\$ 12,000$ for 103.9 acres -367.7 acres would be worth $\$ 42,468$.

235. $\$ 85,000$ (our estimated price for the timber) $+\$ 42,468$ (our estimated price for the 367.7 acres of timberland $)+\$ 15,000$ (our estimated price paid by Townsend for the farmland) $=$ $\$ 142,468$.

236. Interview with John C. Lucy III and John C. Lucy IV, supra note 208. Neighbors and members of the Zehmer family also report that the Ferguson farm had a grand Southern estate house on it. The estate house was torn down sometime after the Lucys bought the property. One neighbor suggests that Lucy sold the house so that it could be taken apart piece by piece and then shipped to and rebuilt by a businessman up North. Interview with Floyd M. Harrison Jr., supra note 110 . We have not been able to confirm this report, but if true, it also would increase the estimated profit that Lucy made from the Ferguson farm. The story is consistent 
together, the evidence convincingly suggests that Lucy, and not Zehmer, reaped windfall profits from the sale enforced by the Virginia Supreme Court in Lucy v. Zehmer.

\section{CONCLUSION}

Prudent parents have reminded their children for generations that money does not grow on trees. Our investigation into Lucy $v$. Zehmer suggests that legal scholars should revisit that conclusion. Money can grow on trees, and it was doing just that in southern Virginia when Zehmer and Lucy met just before Christmas in 1952. The Lucy brothers, understanding that changing circumstances were making southern timberlands more valuable, were quick to capitalize on these developments. Most landowners like Zehmer, by contrast, were slower to understand these trends, even as middlemen like the Lucy brothers expressed considerable interest in what historically had been remote and commercially undesirable lands. ${ }^{237} \mathrm{~A}$ frequent consequence when a broker met a landowner was a speedy sale that the landowner promptly regretted. A long list of litigated cases, some now famous, memorializes the economic and social turbulence that this industrialization stirred.

This was the context in which Lucy met Zehmer for a drink before Christmas in 1952, and understanding this context changes the interpretation of the case. Justice Buchanan, looking at the outward manifestations of Zehmer's reported conduct and believing that $\$ 50,000$ was more than a fair price, concluded that Lucy had been reasonable in thinking that Zehmer had intended to become contractually bound and thus enforced the written instrument. Our

with Lucy's liquidation of other assets on the property and may explain some of the extra profits described by John C. Lucy's descendants.

237. In a sense, Lucy v. Zehmer was rooted in an asymmetry of information between the Lucy brothers-industry middlemen who regularly kept apprised of the industry's growing capacity and demand - and Zehmer-a local landowner who lacked this critical knowledge. Lucy was not the only lumberman to take advantage of his superior knowledge about the value of timberlands. Indeed, a study commissioned by the Virginia legislature found that small sawmills had exploited their market knowledge and the "ignorance" of family landowners. See supra note 180 and accompanying text. Problems arising out of asymmetric information are nothing new to contract law, and courts have grappled with cases arising out of disparities in knowledge between buyers and sellers at least since the Supreme Court's seminal opinion in Laidlaw v. Organ, 15 U.S. (2 Wheat.) 178 (1817). In that case, Chief Justice Marshall, writing for the Court, ruled that a buyer is not obligated to share his superior knowledge with a prospective seller "where the means of intelligence are equally accessible to both parties." Id. at 195. Nonetheless, Chief Justice Marshall warned, "[E]ach party must take care not to say or do any thing tending to impose upon the other." Id. 
research suggests that the value of the farm's timber alone far exceeded $\$ 50,000$. We also know that Dinwiddie County was swarming with aggressive timber brokers like the Lucy brothers, many of whom employed unseemly tactics, many of whom had their eyes on the Ferguson farm, and many of whom - the record indicates as many as twenty-five- had been previously rebuffed by Zehmer. In light of this context of rapidly rising land values and hastily created contracts, one can understand Judge Jefferson's refusal to intervene and enforce the contract.

We conclude that the outward manifestations observed by Justice Buchanan and the Virginia Supreme Court revealed only part of what was well known to the parties-and likely well known to the trial judge as well. Ironically, the historical analysis of the case that is most often used to teach the objective method of contracts in fact demonstrates the deep limitations of that method. Although "objective" connotes a scientific approach, relying on different outward manifestations can lead to different conclusions.

Cicero demanded that historians, above all, must tell the truth. ${ }^{238}$ The story of Lucy v. Zehmer reveals that the truth frequently offers sufficient material for talented historians and creative lawyers to construct alternative narratives. Although our reconstruction of Lucy $v$. Zehmer contrasts sharply with the traditional telling, the case remains a useful tool for studying the objective theory of contracts. Both Justice Buchanan's account and our own are supported by facts. Therein lies the art of the objective method.

\section{POSTSCRIPT}

Five decades after Justice Buchanan issued his opinion in Lucy v. Zehmer, a law professor at the University of North Carolina at Chapel Hill prepared to discuss the case with his contracts class. Surveying the class to select a student to summarize the facts of the case, one name caught his eye. "Mr. Lucy, would you care to share what you know about this case?" That student was John C. Lucy IV, the great-grandson of the original coplaintiff, John C. Lucy. ${ }^{239}$ Once again, a Lucy was being asked to explain the curious events that

238. See 2 CiCERO, De Oratore II 62, at 245 (E.W. Sutton trans., 3d prtg. 1967) ("For who does not know history's first law to be that an author must not dare to tell anything but the truth? And its second that he must make bold to tell the whole truth? That there must be no suggestion of partiality anywhere in his writings? Nor of malice?").

239. Interview with John C. Lucy III and John C. Lucy IV, supra note 208. 
transpired in a Dinwiddie restaurant just days before Christmas in 1952.

Much has changed in Dinwiddie County since that night in 1952. The development of Interstate Highways 85 and 95, for example, has had a devastating effect on local businesses along Highway 1. A drive through the area reveals a virtual rust belt of old hotels and restaurants like Zehmer's place, Ye Olde Virginnie. Even Ye Olde Virginnie is no longer open to those passing through town; instead, in an ironic twist, Ye Olde Virginnie has been transformed into a retirement community. Many of these changes began with the transformation of Virginia's economy in the 1950s and 1960s. And leading the way was Governor Harrison, who is fondly remembered as a driving force behind the modernization of industry across the state. ${ }^{240}$

The Lucy brothers in particular capitalized on these changes. Even as he supplied timber to industry titans, John C. Lucy built his own small timber empire called the Brunswick Box Company. ${ }^{241}$ Originally founded to produce tobacco boxes, the company soon transitioned to manufacturing wood pallets for transporting supplies. ${ }^{242}$ The company is still run by Emory Lucy, one of John C. Lucy's sons. ${ }^{243}$ Another son-John C. Lucy Jr.-founded his own pallet business, the Abell Lumber Corporation, a decade later. ${ }^{244}$ By the mid-1990s, John C. Lucy Jr.'s company had merged with other entities to become Pallet Management Systems, Inc., a multimilliondollar publicly traded company led by John C. Lucy Jr.'s son, John C. Lucy III. ${ }^{245}$ Though briefly successful, Pallet Management Systems experienced financial troubles during a market downturn several years after its incorporation and filed for bankruptcy protection in $2003{ }^{246}$ Despite this loss, John C. Lucy III continues to work as president of Clary Lumber, a hardwood-lumber sawmill located in Gaston, North Carolina, that his father first bought to supply lumber

240. See Saxon, supra note 38 ("Mr. Harrison's time in office came as the state turned from a rural to an industrialized society, and he contributed significantly to that development with road construction and other economic programs.").

241. Interview with Emory Lucy, supra note 118.

242. Id.

243. $I d$.

244. Interview with John C. Lucy Jr., John C. Lucy III, and James Lucy, supra note 113.

245. Marguerite M. Plunkett, PALM BEACH POST, Jan. 28, 1996, at 1E.

246. Interview with John C. Lucy Jr., John C. Lucy III, and James Lucy, supra note 113. 
to the Abell Lumber Corporation. ${ }^{247}$ More than fifty years later, the Lucy family is still picking money off of trees. ${ }^{248}$

Welford Lucy took a slightly different path after Lucy v. Zehmer. In 1954, Welford left Dinwiddie for Warrenton, Virginia, where he purchased a farm to raise cattle and opened a Stuckies store along Highway $17 .^{249}$ Just over a decade later, after making a significant profit selling his Warrenton farm, Welford moved to Richmond to apply his talents to investing in real estate. ${ }^{250}$ Though Welford was initially successful at flipping other properties, his new business slowed down after a bad investment in an office building. ${ }^{251}$ The investment loss was not enough to ruin Welford financially, but it was a painful shock to the ego of a man remembered for his intense pride in his business talents. ${ }^{252}$ He later was sued by the buyer of another property for failing to disclose the existence of contaminated storage tanks that required an expensive cleanup. ${ }^{253}$ Welford lost that dispute, but when all was said and done, he still died a wealthy man. ${ }^{254}$ Family members report that John's and Welford's siblings all exhibited a canny business sense and enjoyed similar financial success, and that each of the five children who grew up on a struggling farm left lucrative estates for their descendants. ${ }^{255}$

The timber industry has changed as well. Regional prices for timber eventually stabilized, and large entities emerged to manage

247. Id.; Interview with Meade Lucy, supra note 119. Welford reportedly had observed how profitable a Stuckey's franchise had been for his daughter and son-in-law and had concluded that he too should pursue the opportunity. Interview with Meade Lucy, supra note 119.

248. Perhaps because of this continued success, members of the Lucy family speak with pride about the business activities of John and Welford-even when discussing the specific case of Lucy v. Zehmer. Interview with John C. Lucy Jr., John C. Lucy III, and James Lucy, supra note 113. They realize, for example, how difficult the task of cruising timberlands and predicting timber prices could be, and they are proud that John and Welford were able, despite their limited educations, to build a burgeoning business from their natural talent and skills. Id. The Zehmers, by contrast, are much more reticent to discuss the case on the record, with one family member acknowledging that the case continues to carry a stigma for the family. Telephone Interview with a Zehmer Family Member, supra note 109.

249. Interview with Meade Lucy, supra note 119.

250. See id. Descendants recall that the development of Interstate 66 near Welford's farm had dramatically raised the value of the property. Interview with John C. Lucy Jr., John C. Lucy III, and James Lucy, supra note 113.

251. Id.

252. Id

253. Emergency Special Servs., Inc. v. Matrix Constr. Corp., 13 Va. Cir. 287, 287 (Va. Cir. Ct. 1988).

254. Interview with Meade Lucy, supra note 119.

255. Interview with John C. Lucy Jr., John C. Lucy III, and James Lucy, supra note 113. 
and harvest timberlands more efficiently than their family-owned predecessors. A majority of the Ferguson farm remains controlled by these interests to this day, with neat rows of pine trees packed together across the expansive property and signs of a small harvest apparent on its periphery.

Perhaps one other thing that will change will be the way law students understand Lucy v. Zehmer. Unlike the caricature portrayed in the contracts classroom, the case involved sophisticated businessmen, a tumultuous economic climate, and the persistent lesson that appellate courts-and generations of contracts scholarsshould be hesitant before confidently claiming to understand the facts of the case before them. 